\title{
Mixing plant species in cropping systems: concepts, tools and models. A review
}

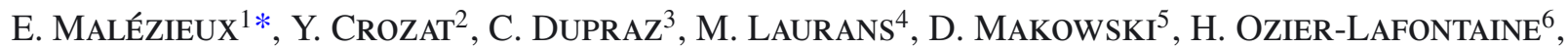 \\ B. RAPIDEL ${ }^{1,7}$, S. de TOURDONNET ${ }^{5}$, M. VALANTIN-MORISON ${ }^{5}$ \\ ${ }^{1}$ CIRAD, UMR SYSTEM, Montpellier, 34060 France \\ ${ }^{2}$ Groupe ESA, Laboratoire d'Écophysiologie Végétale et Agroécologie, 55 rue Rabelais, 49007 Angers Cedex 01, France \\ ${ }^{3}$ INRA, UMR SYSTEM, Montpellier, 34060 France \\ ${ }^{4}$ CIRAD, UMR AMAP, Montpellier, 34000 France \\ ${ }^{5}$ INRA, UMR 211 INRA AgroParisTech, BP 01, 78850 Thiverval-Grignon, France \\ ${ }^{6}$ INRA, Unité AgroPédoclimatique de la Zone Caraïbe, Domaine Duclos, 97170 Petit-Bourg, Guadeloupe, France \\ ${ }^{7}$ CATIE, Turrialba, Costa Rica
}

(Accepted 30 November 2007)

\begin{abstract}
The evolution of natural ecosystems is controled by a high level of biodiversity, In sharp contrast, intensive agricultural systems involve monocultures associated with high input of chemical fertilisers and pesticides. Intensive agricultural systems have clearly negative impacts on soil and water quality and on biodiversity conservation. Alternatively, cropping systems based on carefully designed species mixtures reveal many potential advantages under various conditions, both in temperate and tropical agriculture. This article reviews those potential advantages by addressing the reasons for mixing plant species; the concepts and tools required for understanding and designing cropping systems with mixed species; and the ways of simulating multispecies cropping systems with models. Multispecies systems are diverse and may include annual and perennial crops on a gradient of complexity from 2 to n species. A literature survey shows potential advantages such as (1) higher overall productivity, (2) better control of pests and diseases, (3) enhanced ecological services and (4) greater economic profitability. Agronomic and ecological conceptual frameworks are examined for a clearer understanding of cropping systems, including the concepts of competition and facilitation, above- and belowground interactions and the types of biological interactions between species that enable better pest management in the system. After a review of existing models, future directions in modelling plant mixtures are proposed. We conclude on the need to enhance agricultural research on these multispecies systems, combining both agronomic and ecological concepts and tools.
\end{abstract}

species mixture / plant mixture / cropping system / agroforestry system / agrobiodiversity / resource sharing / crop model / competition / facilitation

\section{INTRODUCTION}

\subsection{Intensive monocultures versus multispecies systems}

Intensive agricultural systems are often based on optimising the productivity of monocultures. In those systems, crop diversity is reduced to one or very few species that are generally genetically homogeneous, the planting layout is uniform and symmetrical, and external inputs are often supplied in large quantities. Such systems are widely criticised today for their negative environmental impacts, such as soil erosion and

*Corresponding author: malezieux@cirad.fr degradation, chemical contamination, loss of biodiversity, and fossil fuel use (Giller et al., 1997; Griffon, 1999; Tilman et al., 2002). Conversely, multispecies cropping systems may often be considered as a practical application of ecological principles based on biodiversity, plant interactions and other natural regulation mechanisms. They are assumed to have potential advantages in productivity, stability of outputs, resilience to disruption and ecological sustainability, although they are sometimes considered harder to manage (Vandermeer, 1989). A majority of the world's farmers, particularly those located in tropical regions, still depend for their food and income on multispecies agricultural systems, i.e. the cultivation of a variety of crops on a single piece of land (Vandermeer et al., 
1998). Those systems, which are often without synthetic inputs and based on integrated management of local natural resources and, in many cases, on rational management of biodiversity, theoretically offer numerous ecological advantages.

\subsection{New issues}

Faced with the critical situation of intensive monocultures, new conceptual ways of constructing sustainable agroecosystems are being sought (Malézieux and Moustier, 2005, b). Several agronomists recently proposed that traditional multispecies systems could be used as models for designing sustainable cropping systems (Gliessman, 2001; Altieri, 2002). Jackson (2002) proposed imitating the structure of the prairie ecosystem, composed of a number of species of different functional groups, to achieve resilience to changes in climate and water supplies, and to pests and other natural disturbances. Ewel (1999) enhanced the role of woody perennial species in the sustainability of ecosystem functioning in the humid tropics and proposed forest-like agroecosystems. Such systems are usually complex, as they are based on several species, and may involve combinations of perennial and annual, woody and nonwoody plants.

Agricultural research now has an adequate tool-box of methods and models for technology development in monospecific cropping systems, but its suitability for more complex systems is unsure. Methods for designing multispecies systems barely exist. Systemic agronomy concepts (crop management sequences, cropping system), and especially the tools derived from that discipline, scarcely deal with the complexity of multispecies systems. In particular, the modelling tools widely used today in agronomy are not well adapted to simulating them. New models are required to represent, assess and design sustainable multispecies cropping systems.

This article addresses those questions, reviews concepts suitable for use in dealing with multispecies systems and attempts to identify shortcomings in terms of tools, thereby proposing new avenues of research. It is based on a wide range of systems, such as simple or complex, uniform or heterogeneous and intercropped species, such as annual and perennial, herbaceous and woody, etc. The article is structured in 3 parts, focusing successively on the following issues: (i) the reasons for mixing species, i.e. benefits and drawbacks, (ii) the concepts and tools used for understanding and designing cropping systems with mixed species, and (iii) the models existing and needed for simulating multispecies cropping systems.

\section{BENEFITS AND DRAWBACKS OF MIXING PLANT SPECIES}

\subsection{The role of biodiversity in ecosystems}

The relationship between biological diversity and ecosystem functions has been and continues to be the focus of much work in the ecology field (Loreau et al., 2001). In contrast with most agricultural systems, biomass productivity in natural ecosystems is achieved through a high genetic diversity of plants involving different complementary functional groups. Although numerous studies report that plant communities with some degree of genetic heterogeneity have advantages over pure stands, debates and controversies remain on the exact role of biodiversity in ecosystem functioning and productivity (Loreau et al., 2001). Recent work by various authors has thus shown positive correlations between the richness of species and different ecological processes such as primary productivity, nutrient retention and resilience after stress. However, studies have particularly focused on natural prairie ecosystems (Hector et al., 1999; Loreau et al., 2001; Tilman et al., 1996, 1997) or natural forest ecosystems (Vila et al., 2003; Kelty, 2006; Erskine et al., 2006). Very few studies have concentrated on cultivated ecosystems (Altieri, 1999). In agroecosystems, biodiversity may (i) contribute to constant biomass production and reduce the risk of crop failure in unpredictable environments, (ii) restore disturbed ecosystem services, such as water and nutrient cycling, and (iii) reduce risks of invasion, pests and diseases through enhanced biological control or direct control of pests (Gurr et al., 2003). Some features of biodiversity in natural systems may offer a basis for designing multispecies systems (Ewel, 1986). For instance, persistent ground cover and minimum soil disturbance, which minimises erosion, is the basis for the development of "conservation agriculture", involving both minimum tillage and cover crop use in annual cropping systems. The frequent presence of deep-rooted perennials in natural ecosystems, one advantage of which is to enable more complementary water and nutrient use by plants, has led to the numerous agroforestry systems that exist in the world. More generally, biodiversity remains the basis for traditional farming in the tropics and multispecies systems still provide food for a majority of poor farmers in developing countries.

\subsection{The different ways to mix plant species in cropping systems}

In world agriculture, a multitude of different cropping systems can be identified on the basis of their composition, design and management. The agroecological areas involved in species mixing extends, in theory, to all cultivated zones, be they temperate or tropical, dry or humid. In what follows, the multispecies systems described consist of growing several crops simultaneously in the same field, or more generally, of mixing several plant species within the same field: field crop species, pasture species, trees, or combinations of these. Multispecies systems have been the subject of numerous typologies and classifications that may include various criteria such as (i) the permanence of a specific crop assemblage or, conversely, the frequency of land-use rotation, (ii) the intensity of intercropping, i.e. the number, type and level of spatio-temporal occurrence of crops within the field, and (iii) the percentage of tree canopy cover in the field (Garcia-Barrios, 2003). The existence of trees with crops (agroforestry) is an important feature and, within that category, the specific arrangement 


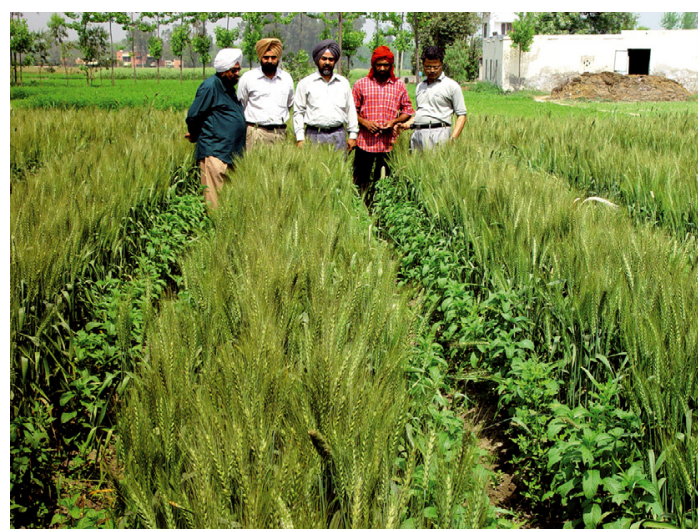

Picture 1. Wheat and mint intercropping in furrow irrigated raised bed systems. Indo-gangetic plain, India. (Courtesy of G. Gupta, with permission of KASSA http://kassa.cirad.fr.)

of species, which refers to the simultaneous or sequential arrangement of trees and crops, or the spatial structure, which refers to the mixed or zonal arrangement, are discriminating factors (Huxley, 1983; Nair, 1993; Torquebiau, 2000). Our aim here is not to give an account of that abundant variability, but rather to highlight the major types existing, bringing out the existence of a multivariate gradient ranging from pure stands (cultivation of a single species, or a single genotype or even a single clone) to cropping systems that function along the same lines as a natural ecosystem. Table I illustrates that variability, with certain properties that might be exerted as soon as genotypes are mixed within the same species. The degree of complexity increases, which might be expressed by the number of intercropped species, the nature of those species (existence to varying degrees of wild species "managed" by the farmer), the number of strata making up the vertical profile, and the simultaneous existence of several groups of species (annual/perennial, woody/non-woody). Pictures 1 to 3 show examples of row intercropping, row agroforestry in Europe and complex agroforestry in the humid tropics, respectively.

\subsection{Advantages of mixing species}

\subsubsection{Effects on stability}

The idea that the species diversity of ecological communities contributes to stability is among ecology's most venerable hypotheses (Frank and Naughton, 1991), but there are few data on how those properties are associated in agroecological systems. Biodiversity is the most obvious feature in multispecies systems, but its real function often remains vague. Some authors (Altieri, 1999; Swift et al., 2004) make a distinction between planned biodiversity, principally the crops and plant species included intentionally in the system by the farmer, and associated diversity, i.e. soil flora and fauna, herbivores and carnivores, decomposers, etc., that colonise the system. Swift and Anderson (1993) proposed a comparable classification of biodiversity in agroecosystems that distinguished productive biota from resource biota (organisms that

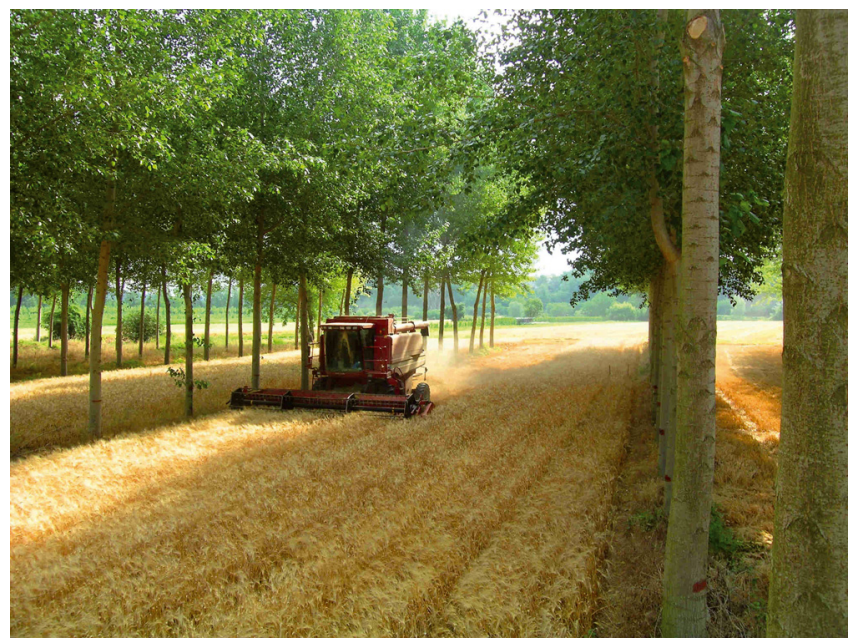

Picture 2. Harvest of a wheat crop in an 8-year-old poplar-cereal intercropping system in the South of France. The poplar density is $75 \%$ of the density of a forestry plantation, and wheat is grown on $85 \%$ of the plot area, resulting in a high relative density, indicating a design that is closer to an additive than a substitutive design. The land equivalent ratio (LER) is over 1.3. (Photo C. Dupraz.)

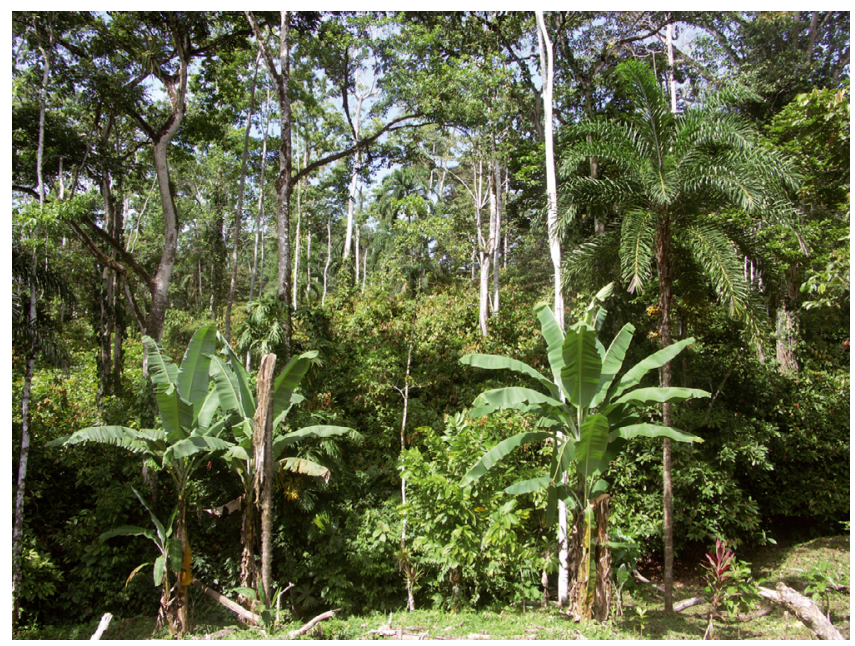

Picture 3. Cocoa agroforestry system in Costa Rica (Talamanca region). Cocoa agroforests include numerous cultivated and subspontaneous plant species i.e. timber trees, fruit trees, palms, banana trees in complex and heterogeneous mixtures. Comparable multistrata systems are found in the humid tropics with coffee, rubber or coconut palms as major cultivated crops. (Photo E. Malézieux.)

contribute to pollination, decomposition, etc.) and destructive biota (weeds, insect pests, microbial pathogens, etc.). It has been reported for numerous taxa in various conditions that associated diversity is positively correlated to planned biodiversity (Vandermeer et al., 1998). A schematic representation of this relation is given in Figure 1. Although the form of the relation between planned and associated biodiversity, and the exact processes involved, remain open questions (Perfecto et al., 1996, Swift et al., 1996), it is certainly a key for understanding the ecological functions offered by multispecies systems 
Table I. Different forms of species mixtures in agricultural systems. Systems are classified according to a gradient of complexity, including the number and type of plant species (annual vs. perennial), the horizontal and vertical structure of the mixture, and the life cycle duration of the species $(\mathrm{S}=$ short cycle, $\mathrm{L}=$ long cycle).

\begin{tabular}{|c|c|c|c|c|c|}
\hline Type of System & $\begin{array}{l}\text { Number of } \\
\text { species }\end{array}$ & $\begin{array}{l}\text { Horizontal } \\
\text { heterogeneity }\end{array}$ & Number of strata & Duration & Example/location \\
\hline \multicolumn{6}{|l|}{ Annual crops } \\
\hline Combination (intraspecific mixture) & 1 & atas & 1 & $\mathrm{~S}$ & Cereals \\
\hline $\begin{array}{l}\text { Relay cropping (time overlap only during } \\
\text { one part of the life cycle of each species) - } \\
\text { Crops or crop and service plant }\end{array}$ & 2 & & 1 or 2 & $\mathrm{~S}$ & $\begin{array}{l}\text { Maize/beans, groundnut/cotton } \\
\text { (Africa) }\end{array}$ \\
\hline $\begin{array}{l}\text { Row intercropping (growing two or } \\
\text { more species in rows) - Crops with crops } \\
\text { or crops with service plant }\end{array}$ & 2 & & 1 or 2 & $\mathrm{~S}$ & $\begin{array}{l}\text { Cereals/herbaceous legumes and } \\
\text { grasses. Ex : Rice/arachis pintoï } \\
\text { (Europe, South America) }\end{array}$ \\
\hline $\begin{array}{l}\text { Mixed intercropping (no distinct row } \\
\text { management) }\end{array}$ & $2-n$ & ations & 1 & $\mathrm{~S}$ & $\begin{array}{l}2 \text { species (maize-sorghum, maize- } \\
\text { cassava, etc.) to n species (tropical } \\
\text { garden e.g. rice, maize, tomato, } \\
\text { cassava, etc.) (humid tropics), annual } \\
\text { grassland (Europe) }\end{array}$ \\
\hline \multicolumn{6}{|l|}{ Perennial crops } \\
\hline Perennial grasses & $2-n$ & & 1 & $\mathrm{~L}$ & $\begin{array}{l}\text { Grassland (North America, Europe, } \\
\text { Australia, etc.) }\end{array}$ \\
\hline
\end{tabular}

Agroforestry (crop with trees)

Sequential agroforestry (crop temporarily mixed with trees)

Row agroforestry.
Crop under service trees

Service plants under tree crop

Tree crops crops)
Herbaceous Crop under tree crop

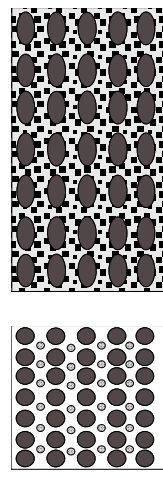

2

2

2

1to 3

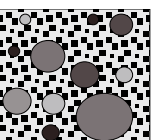

S-L

Pineapple/rubber tree (Humid Asia) maize/ green manure legume tree (Tropics)

Cereal/wood tree (Europe, N.America) Pineapple/coconut tree, pasture/coconut tree (Humid Asia)

Pueraria/oil palm tree (Asia, Africa), Grass/vineyard (Europe)

Cocoa/coconut tree (Oceania) Coffee/wood tree (Central America)

Tropical homegardens; cocoa, coffee and rubber agroforests (humid tropics) 


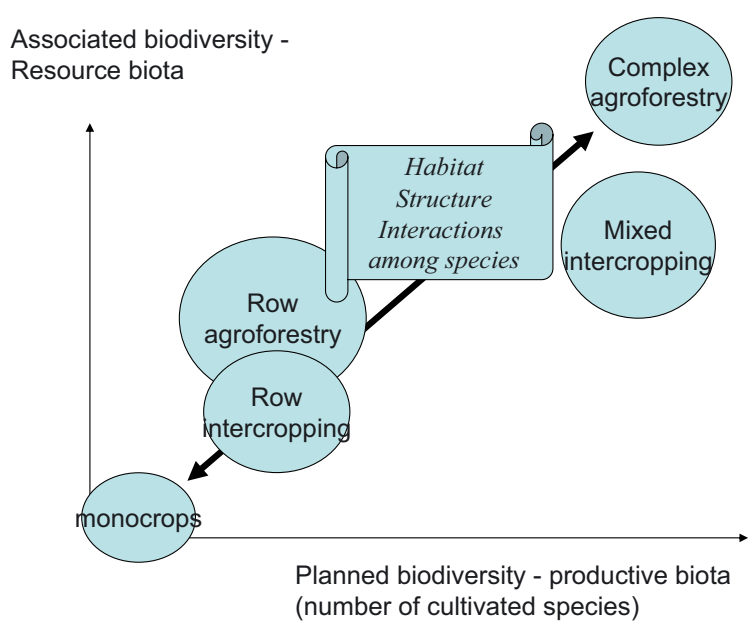

Figure 1. Relationship between planned biodiversity (plant species introduced and cultivated intentionally by the farmer) and associated biodiversity (species that colonize the agroecosystem). (From Altieri, 1999; Vandermeer et al., 1998).

(Altieri, 1999). Intentionally mixing plant species will create new habitats for associated species, mainly when the structure of the system is modified (introduction of trees, for instance). In sole crop systems, the mutually beneficial functions and natural subsidies that lend stability and sustainability to natural systems are usually destroyed and require energy subsidies. According to Hobbs and Morton (1999), the stability and sustainability of managed systems could be increased by replacing external energy subsidies with the mutually beneficial functions found in nature through biodiversity. Hence, multispecies systems might or might not improve productivity, but might improve sustainability by improving the ability to resist or rebound in the face of disruptive effects, i.e. resilience.

\subsubsection{Effects on yield and quality}

The advantage of a mixture has often been assimilated to a higher yield of the mixture when compared with an equal area divided between monocultures of the components in the same proportion as they occur in the mixture. Advantage may also be considered when the yield of the mixture is higher than the yield of its best components grown in a monoculture over the whole of the same area, a less frequent situation called transgressive deviation. In a study based on published data on 344 binary mixtures, Trenbath (1974) reported that most mixtures were recorded as yielding at a level between the yields of the components' monocultures. A minority of mixtures were recorded as yielding outside the range defined by the yields of the components grown in a monoculture.

Mixing species can also influence product quality, although different processes may interfere. In coffee (Coffea arabica L.) agroforestry systems in Central America, shade due to timber or shade trees promotes slower and more balanced filling and uniform ripening of berries, thus yielding a better-quality product than a monoculture of unshaded plants (Muschler,
2001). Fodder quality may be improved when forage is grown under trees, but that is probably due to an improvement in the nutrient balance. Intercropping legumes and cereals may result in a higher nitrogen content in the cereal grains, hence improving that quality criterion (Bulson et al., 1997). In field experiments in Europe in the 2002/03, 2003/04 and 2004/05 growing seasons, intercropping wheat with faba bean (Denmark, Germany, Italy and UK) and wheat with pea (France) regularly increased the nitrogen and sulphur concentration in cereal grains, hence increasing the wheat quality for breadmaking (Gooding et al., 2007).

\subsubsection{Effects on pests and diseases}

Some crop combinations offer advantages in terms of reducing pests and diseases (Trenbath, 1993, HauggaardNielsen et al., 2001). The effect of mixing crops on weed suppression is also well documented (Liebman and Altieri, 1986; Bulson et al., 1997; Welsh et al., 1999; Hauggard-Nielsen and Jensen, 2005) although studies on the mechanisms governing those effects are rare.

Numerous studies have shown a significant reduction in harmful insects in mixed cropping systems compared with monocultures of the same species (Nickel, 1973; Perrin, 1977; Vandermeer, 1989). Andow (1991) analysed 209 studies on crop mixtures involving 287 different species of parasitic insects. The insects were significantly fewer in $52 \%$ of cases (149 species) compared with monocultures, and greater in $15 \%$ of cases (44 species). In conservation tillage agriculture, Dempster and Coaker (1974) found that the use of clover as a cover between rows of brassica crops reduced populations of three insect pests (Brevicorne brassicae L., Artogeia rapae L. and Erioischia brassicae). Andow et al. (1986) showed similar results on insect pests with living mulches interseeded in cabbage.

A particular type of mixed crop is called trap cropping. Trap crops are "plant stands that are, per se or via manipulation, deployed to attract, divert, intercept and/or retain targeted insects or the pathogen they vector, in order to reduce damage to the main crop" (Shelton and Badenes-Perez, 2006).

The reducing effect of crop mixes on diseases (Deadman et al., 1996; Jing Quan Yu, 1999; Kumar et al., 2000; Kinane and Lyngkjær, 2002) or nematode harmfulness (Egunjobi, 1984; Rajvanshi et al., 2002) has been shown in numerous studies.

However, the balance of effects can be complex: for instance, heavy shading in cocoa agroforests may increase pod rot (Phytophthora megakarya), but may at the same time reduce insect (Sahlbergella singularis) attacks and impacts. Reducing or increasing shade intensity by controlling associated forest trees is therefore an important component of integrated pest and disease management in cocoa agroforests (Berry, 2001). The great variability of responses to pests and diseases in multispecies systems therefore requires a clearer understanding of the mechanisms involved in those biological interactions. 


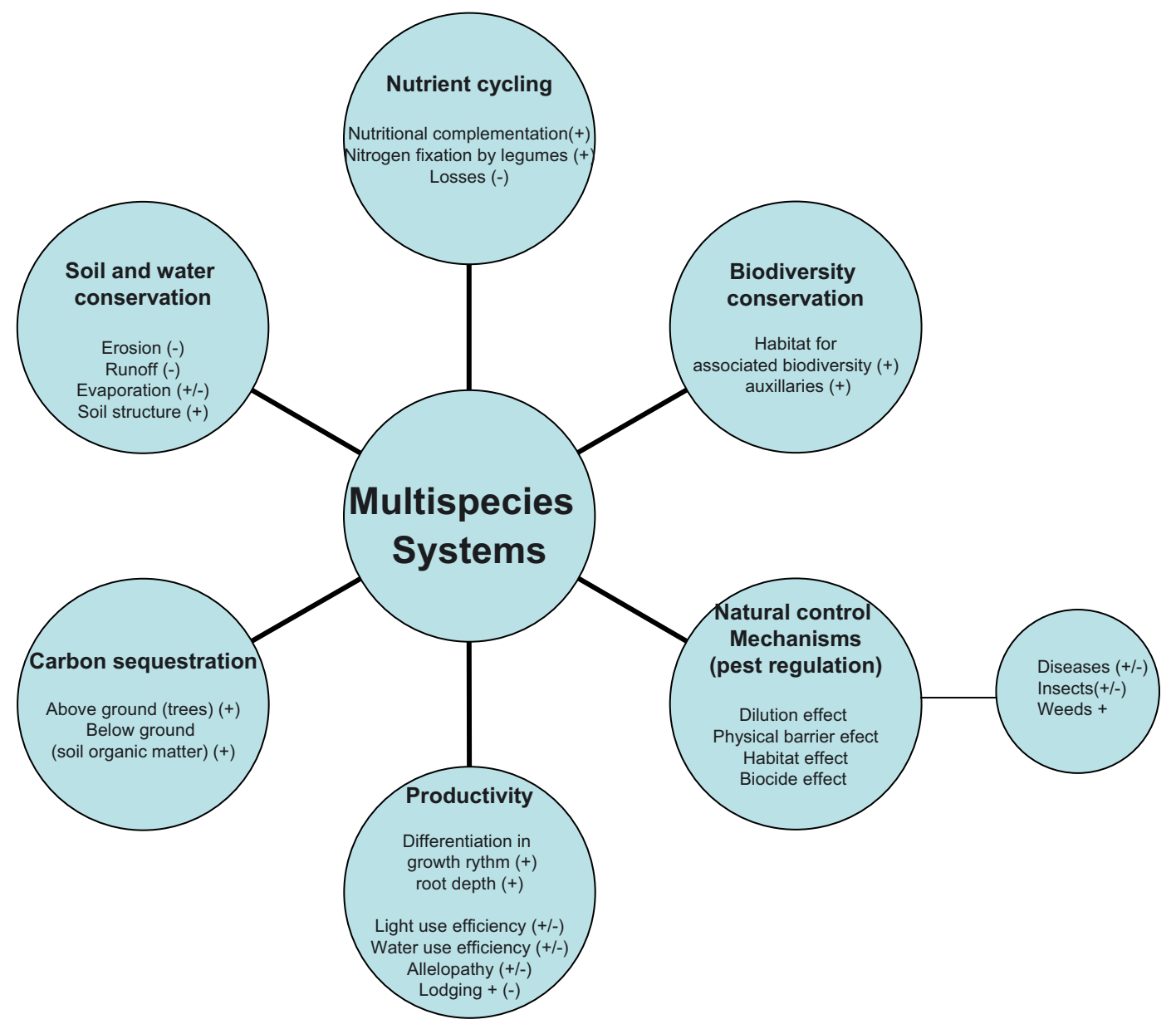

Figure 2. Processes and induced properties in multispecies systems.

\subsubsection{Environmental impacts}

In addition to agricultural products, multispecies systems may provide environmental services that have impacts beyond the field scale, either spatially, e.g. services to the local or the global community, or temporally, e.g. modifications of the environment for future generations. Factors that interact in multispecies systems and may impact on both production and protection functions are summarised in Figure 2. The most documented environmental services are related to the following areas:

(i) Biodiversity conservation: the enhanced diversity of plants in a field may host a larger range of species, from plants to insects, birds to mammals, above- or belowground (Brussaard et al., 2007; Perfecto et al., 2003) (Fig. 1). For crops such as coffee and cocoa, biodiversity often differs less between natural habitats and low-intensity multispecies systems than it does between low-intensity and high-intensity systems (Donald, 2004). Beyond conservation issues, higher biodiversity can have local effects, such as greater resilience to abiotic or biotic disruptions, particularly through greater microbial diver- sity in the soil (Giller et al., 1997; Altieri, 1999; Swift et al., 2004).

(ii) Nutrient recycling by coexisting species exploring different soil depths: this has been particularly documented in agroforestry systems where the deeper rooting system of trees brings up nutrients from deeper soil layers, increasing nutrient-use efficiency and reducing nutrient leaching from the soil layers explored by the crops (van Noordwijk et al., 1996).

(iii) Soil conservation and water quality: multispecies systems may increase soil cover, root presence in the topsoil and obstacles to run-off on the soil surface, hence decreasing soil erosion, having a positive impact, on a watershed scale, on the water quality of rivers, and on the intensity of floods (Swift et al., 2004).

(iv) Multispecies systems can sequester carbon over pure crop stands. Trees and/or cover crops (Vandermeer et al., 1998; Scopel et al., 2005) may also enhance the soil carbon content, thus participating in climate change mitigation.

Multispecies systems can also provide other services, linked to the quality of the environment: trees over crops can provide shade and shelter for animals and humans, and, on a 
landscape scale, enhance the aesthetical value of land. However, such services are difficult to assess.

\subsubsection{Economic profitability}

The economic profitability of multispecies systems is firstly related to their productivity. Despite difficulties due to the number of products involved, specific tools have been developed to assess that productivity. The LER concept (Land Equivalent Ratio, developed hereafter) has been extended to take into account the duration of land occupancy by crops (Area $\times$ Time Equivalence Ratio, ATER) or to incorporate monetary returns (Monetary equivalent ratio, MER). However, other issues have to be considered when assessing economic profitability (Follis, 1993):

(i) Product time range

When setting up perennial plantations such as oil palms or rubber trees, crop mixing is widely used to generate income in the first years of the plantation, when the palms or trees are still unproductive, do not produce any economic returns and also occupy a confined field space. As investments and products are needed or delivered at different times, a financial appraisal of these agroforestry systems calls for tools developed to assess forestry projects, such as Discounted Cash Flow, and the results of the comparisons depend on the discount rate chosen. Nevertheless, most studies show an economic advantage for multispecies systems used for that purpose, when compared with pure forestry projects.

(ii) Income stability

Stability has often been presented as the main reason for adopting multispecies systems in situations exposed to risk, such as poor tropical agriculture. Multispecies systems that provide several products can maintain a more stable income, particularly if price variations for those products are not correlated. Multispecies systems also often require lower external fertiliser and pesticide inputs. That lower dependence on external inputs makes multispecies systems more resilient to external changes, such as product prices.

Intercropping a new crop with a traditional crop is also a way of cautiously entering a new market, without much knowledge, as shown by fruit production in cocoa agroforestry systems in Cameroon.

(iii) Evaluation of ecological services

Multispecies systems may also offer ecological services, either for the internal benefit of the fields in which they are cultivated (pollination or soil conservation) or for external benefits, such as water quality, biodiversity or the beauty of the landscape. Valuing those services is becoming an important issue, to incorporate them into the economic appraisal of cropping systems. Several examples exist of payment for such services, particularly in Latin America, but accurate assessment is still needed.

(iv) Labour productivity

Mixing is also assumed to be conducive to an adequate distribution of labour over the year. Unfortunately, very little on-farm research has been published on labour distribution and labour productivity in multispecies systems compared with pure crops. Some data are available on annual intercrops, such as the "abonera" system in Honduras, where velvet bean (Mucuna deeringianum) is sown in the rows of corn. That system shows higher labour productivity, even after the second year of establishment, whatever the discount rate chosen. In Brazil, the direct sowing mulchbased cropping system, combining cover crops before, after or during the main crop, is widely adopted on mechanised farms. The adoption of these systems by smallholders is mainly motivated by labour savings, but precise labour data are not available. Multispecies systems may also favour the equity of income distribution within the family, as in West Africa, where, for instance, nuts of the shea tree (Vitellaria paradoxa) scattered in the fields are for the exclusive benefit of women.

Although frequent, the advantages and benefits of multispecies systems must not be overgeneralised: not all crops are beneficial in mixtures, since they do not systematically generate ecological and/or economic benefits, and may involve more complex or higher inputs of labour. Even when advantages are recognised, multispecies systems are sometimes more difficult to manage and require substantial farmer skills and specific research efforts.

\section{CONCEPTS AND TOOLS NEEDED FOR UNDERSTANDING AND DESIGNING MULTISPECIES SYSTEMS}

\subsection{The conceptual frameworks of agronomy and ecology}

\subsubsection{The framework provided by agronomists}

Agronomy is a discipline that concentrates on both the biophysical functioning of the cultivated field, and on the reasoning of actions taken in plant production (Sébillotte, 1978; Doré et al., 2006). Progress in understanding plant-soil interactions on a field scale has been widely based on a simplification of reality, the cultivated plant stand being assimilated to a single homogeneous crop. A widely-used approach in agronomy is big leaf representation based on an energy balance where the plant stand is assimilated to an area of thermodynamic exchange with its surrounding environment. That approach, which is very robust for describing biomass growth in pure crops (Monteith, 1977; Gosse et al., 1986), has also been used on sparse crops and to some extent on multispecies systems, by cutting the plant cover into horizontal sections to take into account the vertical heterogeneity of the stand (Wallace et al., 1991). Whilst it has given some interesting results, particularly for characterising competition for light and its impact on biomass (Wallace et al., 1991; Keating and Carberry, 1993; Cruz and Sinoquet, 1994), a functional approach to the plant 
stand becomes necessary to account for competition and facilitation processes in the canopy (see below). A similar approach was used for soil and root colonisation in the different soil layers, with similar limits. Using indicators established on monospecies stands can raise problems for multispecies stands; that is notably the case with $\mathrm{N}$ because the nitrogen nutrition index is difficult to interpret for intercrops (Corre-Hellou, 2005). One of the essential limits for applying the usual agronomic approaches to multispecies systems is therefore to consider the plant stand as a collection of identical individuals. Some attempts to consider canopy heterogeneity and its dynamics have appeared recently for pure stands, allowing for the consideration of emerging properties of the system due to canopy heterogeneity and its evolution: for instance, cohort models have been used to represent and simulate intraspecific heterogeneity in pure stands of bananas due to phenology lags (Tixier et al., 2004). Architectural representations that consider the plant stand as a sum of differentiated individuals are doubtless another efficient way of representing multispecies system functioning, since they can integrate environmental heterogeneity and the impact of architectural organisation on the functional activity and phenotypical plasticity of plants (Soussana and Lafargue, 1998; Prusinkiewicz, 2004).

As regards the reasoning of actions, agronomy has produced a theoretical corpus based on decision rules for crop management, incorporated into cropping system (Sébillotte, 1974, 1978, 1990), technical system (Osty et al., 1998) or action model concepts (Aubry et al., 1998). Agronomists can call upon methods developed for evaluation and design: multicriteria evaluation (Rossing et al., 1997; Loyce et al., 2002), agronomic diagnosis (Doré et al., 2008), designing based on models or expert evaluations. All these concepts and tools should be applicable to multispecies systems as they account for interactions between techniques, long-term cumulative effects and multi-criteria objectives for a crop. However, whilst not ruling them out, they do not facilitate the consideration of characteristics such as heterogeneity and the numerous interactions between individual plants specific to multispecies systems. Hence, multispecies systems require the development of new knowledge, as intercrops involve more complex functions when compared with the respective sole crops. It also calls for the designing of decision rules enabling coordinated management of several cultivated species and even, in some cases, sub-spontaneous species that may have different functions. The complexity of multispecies systems and the specific properties that emerge from them often make it difficult to accept the hypothesis of homogeneity that lies at the basis of many agronomy tools. It may therefore be necessary to revise the concepts used and develop specific, new models and tools.

\subsubsection{The framework provided by ecologists}

The relations between plant interactions and plant community structures have long received the attention of ecological research (Clements et al., 1926). The question of how biotic diversity and ecosystem functions are related is now consid- ered one of the fundamental questions in ecology (Hobbs and Morton, 1999). In natural systems, the composition of plant species can change in line with a productivity (resource) gradient (Tilman, 1984). For instance, species richness may decline as soil fertility increases (Abrams, 1995). The research conducted by ecologists therefore provides a rich theoretical framework for approaching the role of biological diversity in ecosystem functioning. However, attempts to apply that theoretical framework to cultivated ecosystems are few and far between. Main (1999) addressed the important question of how much biodiversity is enough in an agricultural context. There is certainly no absolute answer to that question, because all systems are dynamic and solutions may depend on place and time, and also because criteria need to be specified to address the sustainability of cropping systems or agriculture. The answer should be more qualitative than quantitative: the ecologists Ewel and Bigelow (1996) emphasised the fact that the mix of life-forms, not the mix of species, exerts control on ecosystem functioning.

That framework provided by ecology primarily relies on three principles based on the hypotheses of complementarity, facilitation and selection of species possessing particular traits (Erskine et al., 2006). The principle of complementarity considers that the diversity of ecological attributes arising from a large number of species provides easier access to limited resources. The principle of facilitation suggests that overall productivity can be increased when some species, e.g. nitrogenfixing species, can enhance the growth of other species. The principle of selection or sampling assumes that systems containing a large number of species have a greater probability of containing species that are highly adapted to the limiting conditions faced by the system. The diversity of species may also reduce instability in the ecosystem processes through asynchronous responses of the different species to environmental fluctuations. Those different aspects enable ecologists to interpret the effects of biological diversity in ecosystems based on two major variables of the ecosystem: its productivity, often measured by the biomass present, and its stability. Despite the wide range of applications, few studies have been conducted to analyse the relevance and applicability of those three principles for cropping systems. However, whilst the principles of complementarity and facilitation could be tested in an agricultural context, the theoretical principle of the effect of selection or sampling cannot be easily studied because mixtures of species in cropping systems do not give rise to random distribution but to a deliberate choice, reasoned and guided by the farmer.

Taking into account competition between species is a preferential point of entry for both agronomy and ecology, which has strongly influenced the concepts and tools developed by the two disciplines. Competition has received close attention in ecological research (Keddy, 1989; Goldberg and Barton, 1992) but the explicit consideration of the facilitation principle might renew the concepts and tools, as shown by Bruno et al. (2003). By shifting the balance between competition and facilitation towards facilitation processes (Callaway and Walker, 1997; Anil et al., 1998), multispecies systems form a new element at the interface of the two disciplines. 

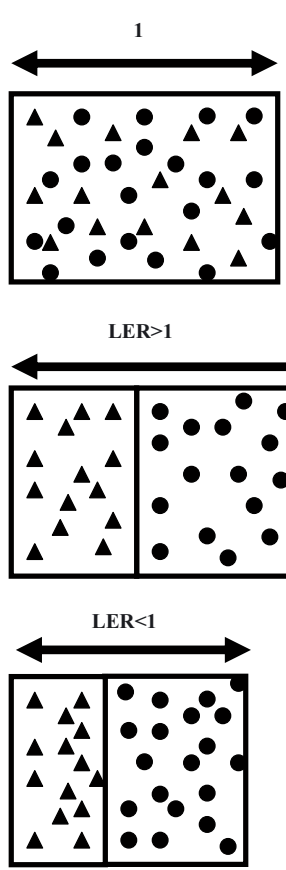

(a)
$\mathrm{D}_{1}$
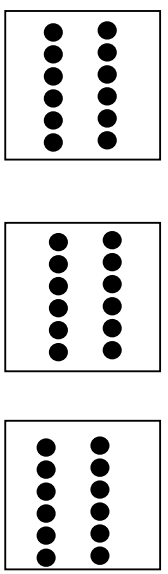

$\mathrm{D}_{2}$
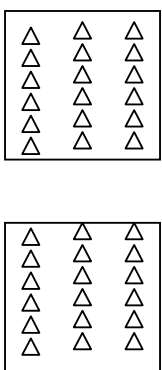

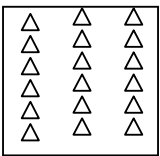

$\mathrm{d}_{1}+\mathrm{d}_{2} \quad$ DER $=\mathrm{d}_{1} / \mathrm{D}_{1}+\mathrm{d}_{2} / \mathrm{D}_{2}$

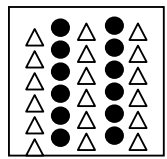

Additive design $: \mathrm{DER}=2$

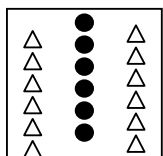

Substitutive design $: \mathrm{DER}=1$

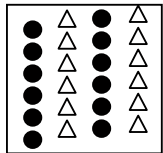

(b)

Figure 3. Land and density equivalent ratios. (a) The land equivalent ratio (LER) of a multispecies system is the area needed to produce the same outputs as one unit of land with a pattern of sole cropping; (b) the density equivalent ratio (DER) indicates the crowding of the mixture. The symbols represent the plant population density.

\subsection{Measuring multispecies system productivity}

Simple methods can be used to assess the benefits of multispecies systems by estimating their productivity using the Land Equivalent Ratio (LER, Mead and Willey, 1980). LER compares the yields obtained by growing two or more species together with yields obtained by growing the same crops as pure stands. For two mixed species, the LER equation is as follows:

$$
\text { LER }=\text { mixed yield } 1 / \text { pure yield } 1+\text { mixed yield } 2 / \text { pure yield } 2
$$

The resulting LER indicates the amount of land needed to grow both species together compared with the amount of land needed to grow pure stands of each (Fig. 3a). A LER greater than 1.0 indicates mixed systems are advantageous, whereas a LER less than 1.0 shows a yield disadvantage.

A Density Equivalent Ratio (DER) can be defined as a measure of the crowding of the mixture:

DER $=$ mixed density $1 /$ pure density 1

+ mixed density $2 /$ pure density 2

Additive, substitutive and intermediate designs may be used to combine species in mixed cropping systems (Fig. 3b). The key assumption in the use of the LER is that the densities of plants in the sole cropping controls are close to the optimum. The null hypothesis $(\mathrm{LER}=1)$ means that inter- and intraspecific interactions are equivalent.

The properties of multispecies systems are not always derivable from the properties of individual species. Collective dynamics may lead to emergent properties that cannot be deduced from species properties alone, i.e. redistribution of the soil-water resource by shrubs in agroforestry systems. This makes it more complicated to define a proper methodology for studying multispecies systems compared with studies involving one species.

Loreau and Hector (2001) developed an approach to separate the 'selection effect' from the 'complementary effect' in ecological systems. According to these authors, a selection effect occurs when changes in the relative performances of species in a mixture are non-randomly related to their performances in a monoculture. In their approach, the authors proposed measuring the selection effect in a mixture of $N$ species by a covariance function derived from the Price equation in evolutionary genetics (Price, 1970, 1995). Here, we propose an adaptation of that function, which could be used by agronomists to estimate the selection and complementary effects resulting from a mixture of several cultivated species.

Let us consider $N$ species cultivated in a monoculture in $N$ fields with areas equal to $s_{1}, \ldots, s_{\mathrm{i}}, \ldots, s_{N}$, respectively. Note $z_{i}=s_{i} \times y_{i}$ the crop product obtained with a monoculture of the $i$ th species in the $i$ th field, where $y_{i}$ is the crop product per unit area. Crop products can be expressed as yields or as gross margins. It is more worthwhile expressing $y$ and $z$ as gross margins when the monetary prices of the crops are very different.

Now, let us consider a mixture of the $N$ species. Note $z_{i}^{\prime}=$ $s_{T} \times y_{i}^{\prime}$ the crop product obtained for the $i$ th species when the $\mathrm{N}$ species are cultivated as a mixture on a total area defined by 
$s_{T}=s_{l}+\ldots+s_{N}$. Then, the covariance function defined by Loreau and Hector (2001) can be expressed as:

$$
\operatorname{cov}\left(R_{z_{i}}, z_{i}\right)=\frac{1}{N} \sum_{i=1}^{N}\left(R_{z_{i}}-\bar{R}_{z}\right)\left(z_{i}-\bar{z}\right)
$$

where $R_{z_{i}}=\left(\frac{z_{i}^{\prime}}{z_{i}}-1\right)$ is the relative gain for the $i$ th species which results from the mixture of the $N$ species.

According to Loreau and Hector (2001), the covariance equation (1) can be used to measure the 'selection effect'. A positive covariance indicates that the highest relative gains $R_{z_{i}}, i=1, \ldots, N$, are obtained for the species giving the best results when cultivated in a monoculture. On the other hand, a covariance near zero indicates that those relative gains are not linked to the performance of the $N$ species in the monoculture.

A small covariance does not necessarily indicate that the overall gain resulting from the mixture of the $N$ species is small. Indeed, it is easily shown that the overall gain is a sum of two terms:

$$
\Delta=\sum_{i=1}^{N} z_{i}^{\prime}-\sum_{i=1}^{N} z_{i}=N \times \operatorname{cov}\left(R_{z i}, z_{i}\right)+N \times \bar{R}_{z} \bar{z}
$$

where $\Delta$ is the overall gain resulting from the mixture of the $N$ species, $\bar{z}=\frac{1}{N} \sum_{i=1}^{N} z_{i}$, and $\bar{R}_{z}=\frac{1}{N} \sum_{i=1}^{N} R_{z_{i}}$. The first term is proportional to the covariance $\operatorname{cov}\left(R_{z_{i}}, z_{i}\right)$ and the second term is proportional to the average value $\bar{R}_{z}$ of the relative gains obtained for the $N$ species. This second term can be used to measure the complementary effect of the species in the mixture. A positive value of $\bar{R}_{z}$ indicates that, on average, the relative gains obtained for the different species are positive.

\subsection{Resource sharing in multispecies systems}

\subsubsection{The principle of competition versus facilitation}

Referring to Vandermeer (1989), "competition is the process in which two individual plants or two populations of plants interact such that at least one exerts a negative effect on the other, while facilitation is the process in which two individual plants or two populations of plants interact in such a way that at least one exerts a positive effect on the other; double facilitation is equivalent to mutualism". Multispecies systems may maximise beneficial interactions while minimising competition. In comparison with homogeneous pure cropping systems, different species that are sharing a common space interact together and with the environment in an information feedback loop, where the environment affects the plants and the plants reciprocally affect the environment (Fig. 4). These types of interactions give them a set of properties including competition for space, competition for light between canopies, and competition for water and nutrients between root systems.

The agronomic advantages of multispecies systems are the result of differences in the competitive ability for growth factors between plant components. In terms of competition,

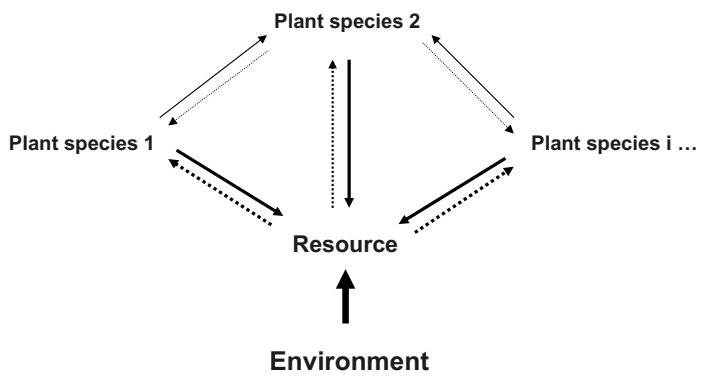

Figure 4. Interaction between plants for resources (from Grace and Tilman, 1990). In this context, plants have an effect on the abundance of a resource and other plants respond to the change. Both the effect $(-)$ and the response $(---)$ must be of appropriate sign for competition to occur.

this means that the components are not competing for the same ecological niches and that interspecific competition is weaker than intraspecific competition for a given factor (de Wit and Van den Bergh, 1965). The ecological niche concept (Vandermeer, 1989) underlies the fact that the different species involved may have different resource requirements at different times, as well as different sources of nutrition, e.g. root exploitation of superficial soil layers by one species versus deeper exploitation by the other, different growth patterns, or different affinities for the same nutrient, e.g. nitrogen in $\mathrm{NO}_{3}^{-}$ form versus $\mathrm{NH}_{4}^{+}$available form.

\subsubsection{Aboveground competition for light}

Of all the major environmental factors that contribute to reported multispecies system merits, the capture and use of solar radiation is the one that has received the most attention (Keating and Carberry, 1993). Overyielding by mixtures has often been attributed to a more efficient use of light by their canopies. Trenbath (1974) reported that an "ideal" leaf arrangement could be approached by a mixture of a tall erect-leaved genotype and a short, prostrate-leaved genotype. Among aboveground factors, the factors that affect the light regime of plant canopies are the amount of light and quality of incident radiation, the canopy architecture and the optical properties of the leaves and the soil (Sinoquet and Caldwell, 1995). In comparison with pure, uniform stands, light capture depends on (i) the fraction of incident photosynthetically active radiation (PAR) that is partitioned by heterogeneous canopies and intercepted by each species, and (ii) the efficiency with which intercepted radiation is converted by photosynthesis. While direct measurement techniques have been slow to develop, light modelling within multispecies systems has quickly matured (Sinoquet and Caldwell, 1995). A number of models are now available with different levels of complexity for multispecies systems, but field applications face some practical limitations. Compared with pure stands, multispecies systems contain significant spatial variations in leaf area density and leaf angle distribution that are difficult to simulate. 


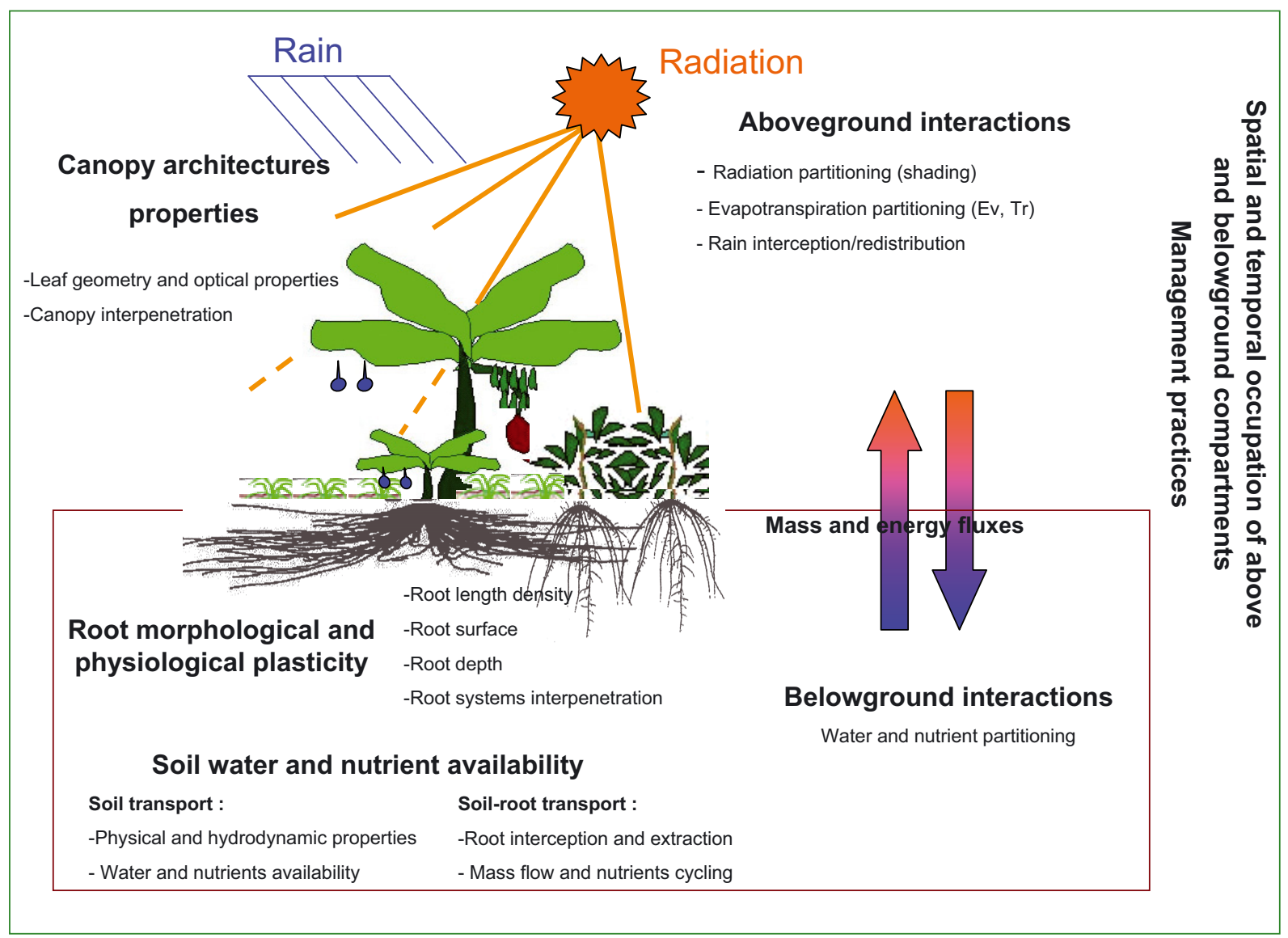

Figure 5. Above and belowground competition for resources in multispecies systems. The functionning of such systems is not only conditioned by the availability of environment resources but also by the ability of the component species to share them.

\subsubsection{Belowground competition for water and nutrients}

Belowground competition occurs when plants decrease the growth, survival or fecundity of neighbours by reducing available soil resources. Contrary to aboveground competition, which primarily involves a single resource, light, plants compete for a broad range of soil resources including water and at least 20 mineral nutrients that differ in molecular size, valence, oxidation state and mobility within the soil (Casper and Jackson, 1997). The components of the mixture may be complementary in a spatial sense by exploiting different layers of the soil with their root systems. Components of a mixture may complement each other nutritionally (different needs in quantities, preferential use of different chemical forms). Mixtures of leguminous and non-leguminous species are well known in that regard, and provide repeatable examples of overyielding due to nutritional complementation. To study those interactions, three aspects have to be taken into account that address the resource supply to the roots, the characteristics of the root system, and the demand for water and carbon allocation, respectively (Fig. 5):

(i) Resource supply to the roots involves four main processes: the distribution of resources in the soil and their availability, which depends on soil biophysical and chemical properties, interception by the roots $(<10 \%)$, mass flow, which affects water and mobile nutrients such as $\mathrm{NO}_{3}^{-}$, and diffusion, which affects nutrients such as $\mathrm{P}$ and $\mathrm{K}$.

(ii) Root system characteristics include morphological plasticity - root location in time (Caldwell and Richards, 1986) and space (de Willingen and Van Noordwijk, 1987), investment in root biomass, root length or surface - and physiological plasticity - rate of resource uptake in relation to enzyme functioning.

(iii) The demand for water. Water distribution depends on the partitioning of evaporative demand between the species' components, and on soil evaporation (Ozier-Lafontaine et al., 1997, 1998).

An analysis of the belowground processes and resource use by plants presents tremendous challenges as there are still general methodological difficulties despite the advances made in techniques and equipment design. For example, roots of the component plants can intermingle (Gregory and Reddy, 1982), making the task of separating the respective root systems very cumbersome. Staining techniques generally fail to distinguish one root system from another. Other possibilities, such as 
isotopic discrimination of $13 \mathrm{C}$ between $\mathrm{C} 3$ legumes and $\mathrm{C} 4$ cereals are efficient but require special equipment (Wong and Osmond, 1991; Lichtfouse, 1997).

\subsubsection{Intercrop and resources}

For a long time, plant ecologists have intensively studied competition and facilitation along resource gradients (Donald, 1958; Grime, 1977; Tilman, 1988; Wilson and Tilman, 1988). However, empirical results and theories remain controversial (Garcia-Barros, 2003). Schematically, competition might be high in a high resource environment, while facilitation might be greater under harsh conditions (Bertness and Callaway, 1994). More generally, the interpretation of interactive effects between intercrop component activities and resources in the environment is extremely complex. For example, specific crop growth affects soil shading and light interception and therefore also temperature; plant water uptake changes soil water content in the rhizosphere, which affects microbial decomposition rates; decomposition rates affect soil texture, water-holding characteristics, rooting profiles and nutrient availability for crops. It remains very difficult to disentangle those processes experimentally. Thus, dynamic simulation models of those systems are valuable for interpreting all these processes and interacting conditions (see Sect. 4).

\subsection{Biological interactions}

These refer to a variety of processes that include allelopathy and competition with weeds, along with pest and disease interactions with plants.

\subsubsection{Interactions with weeds}

Two types of action are identified to explain the reduction in weed biomass frequently observed: (i) competition for resources such as light, water, nitrogen or other nutrients, and (ii) allelopathy (Liebman and Dyck, 1993), though the distinction between those effects sometimes remains difficult.

Allelopathy refers to inhibition of the growth of one plant by chemical compounds released into the soil from neighbouring plants. It may inhibit a mixture: tree species such as Gliricidia sepium or Leucaena leucocephala used in agroforestry are reported to have allelopathic effects on maize and rice seedlings (Nair, 1993). Conversely, the use of specific species may enable better control of weeds and thereby be a benefit of mixing. However, little is known about allelopathic mechanisms for weed control in a mixture. Beyond those allelopathic mechanisms, the suppressive effect on weeds is observed through competition when the cultivated species are complementary in resource uptake: nitrogen requirements (legumes versus other plants), photosynthesis metabolism ( $\mathrm{C} 3$ versus $\mathrm{C} 4$ plants) and different soil exploration by roots depending on the species. The complementarity between cultivated species often makes it possible to capture a greater quantity of resources in the case of intercrops versus pure stands, thereby reducing the resources available for weed growth (Liebman and Dick, 1993; Bulson et al., 1997; Hauggaard-Nielsen et al., 2001; Hauggaard-Nielsen and Jensen, 2005). In mixtures combining a cereal and a legume, the greater competitiveness of the mixture compared with monocultures is due to the fact that cereals are more competitive than legumes in taking up nitrogen from the soil due to faster root development and demand (Corre-Hellou et al., 2006). Mixing species may also reduce the specific diversity of the weed stand and lead to a change in biomass distribution between weed species (Poggio, 2005).

\subsubsection{Interactions between crop mixtures and diseases and pests}

In order to explain interactions between mixtures and diseases and pests, a distinction is made between different processes:

(i) The dilution effect

The hypothesis of resource concentration put forward by Root (1973) reflects the fact that the mixture gives rise to a "dilution" of the host plant in the plant cover, making the parasite or pest less efficient at locating and colonising its host plants. An increase in the proportion of nonhost plants in a mixture enhances that effect (Sibma et al., 1964; Trenbath, 1993).

(ii) The physical barrier effect

The previous theory of Root (1973) is completed by the disruptive crop hypothesis (Vandermeer, 1989). By modifying the structure of the stand and the architecture and microclimate of the cover, the mixture modifies the location of the host plant, thereby affecting disease spread or disrupting the parasitic insect's search for feeding or mating sites (Francis, 1990). Conventional cereal crops can disrupt insects in their visual search for smaller crops (Ogenga-Latigo et al., 1992), and the existence of a lower crop storey may, likewise, affect the visual search for a potential host.

(iii) The habitat effect

Introducing species with a contrasting plant architecture creates a new habitat which in turn modifies populations of predators. For instance, Jones and Sieving (2006) reported a change in the behaviour of insectivorous birds with the introduction of a single row of sunflowers in organically grown vegetables.

(iv) The chemical effect

A mixture may contain species that produce substances that have negative effects on diseases and pests, such as nematodes, that are parasites on another component in the mixture. That is the case for certain intercropping systems based on cover crops dedicated to controlling nematodes (Yeates, 1987; Rodriguez-Cabana and Kloepper, 1998). Those different effects can be combined in different ways: for example, cover crops used in mixtures may affect plant parasitic nematodes (a) as non-host plants affecting nematode reproduction, (b) by producing root exudates stimulating nematode reproduction in the absence 
of hosts and causing nematode death, (c) by producing root exudates with nematicide properties, and (d) by producing compounds in the foliage which, once incorporated into the soil, have nematicide properties. Functions (a) and (d) can be utilised in crop rotations, where they ensure a preventive function (cleansing), whilst functions (b) and (c) can be taken advantage of in mixtures, as those two control methods can be utilised in overlapping cycles.

\section{MODELLING PLANT MIXTURES}

\subsection{The state of the art}

Models of plant mixtures apply to various systems: crops and weeds, mixtures of crop varieties, intercropping of different crop species, tree and crop mixtures (agroforestry, treeshelters), and tree species mixtures (mixed forests). The nonlinear behaviour of multispecies systems cannot be accounted for by simply studying or modelling plant components independently.

\subsubsection{Modelling is the only way to go with multispecies systems}

Design decisions made from the small amount of empirical evidence from the few available trials on multispecies systems are inherently weak, as plant development and productivity in mixtures are site- or weatherspecific (Vandermeer, 1989). Land Equivalent Ratio assessments based on a few years of measurements are highly questionable (Vandermeer, 1989). In mixture studies, innovative planting designs have been developed to reduce the land area needed for mixed-species plantation experiments, by focusing on individual plant analysis rather than plot-level analysis (Kelty, 2006). However, the numerous combinations between species, environments and practices are not within reach of traditional factorial experimental approaches. In dynamic systems with heterogeneous structures, a system approach is required to improve understanding of the processes involved, and to evaluate adequate management schemes. There is a need for dynamic modelling tools to evaluate how wide ranges of soil conditions, various weather sequences and different management schemes modify the yield and environmental impact of multispecies systems.

\subsubsection{Modelling interspecific relationships}

All models of multispecies systems simulate interspecific interactions which are key determinants of the structure, the dynamics and the productivity of mixed plant communities. As seen previously, in contrast with sole cropping, multispecies systems have parallels with basic ecological principles. Plant interaction models are categorised as being either empirical, providing only a description of the outcome of competition,

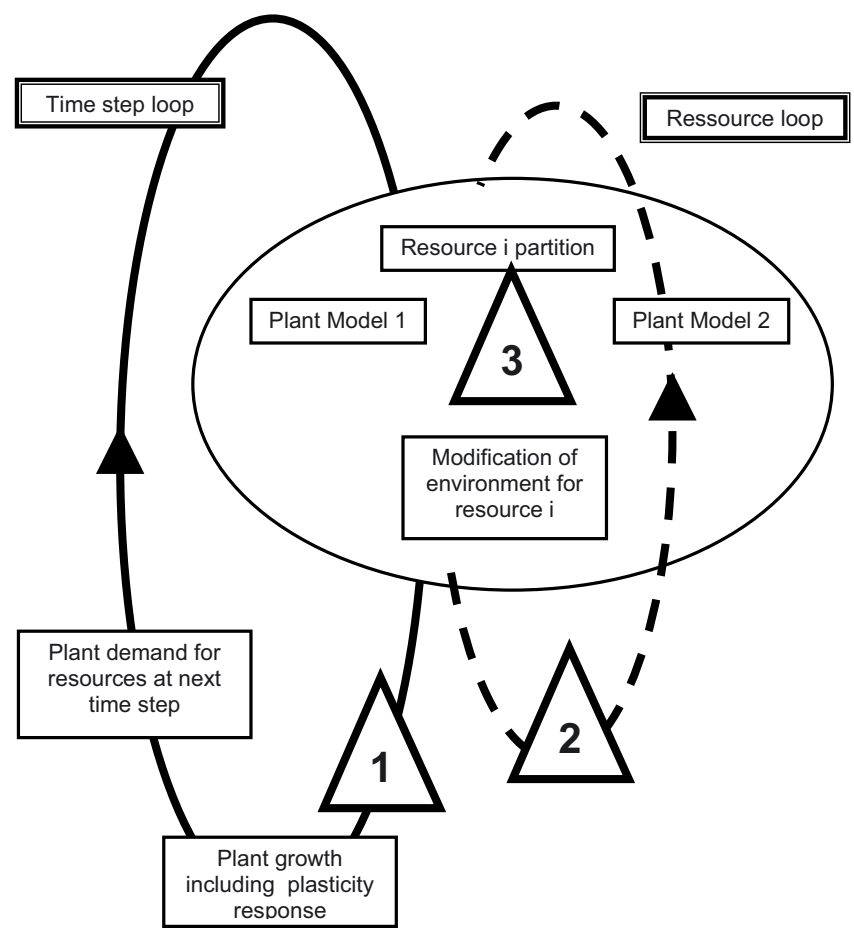

Figure 6. The three crux of multispecies dynamic models for resource partition: including appropriate plasticity mechanisms in the plant models (1), solving the resource sharing for multiple resources simultaneously (2), and coupling plant models often built with different concepts (3).

or process-based, offering a representation of the physiological processes underlying plant growth. Empirical models are useful for making predictions within the range of data used to parameterise them but are not suitable for extrapolation. Mechanistic models that are based on the behaviour of individual plants are based on "focal plant-neighbour plant" interactions. In contrast to empirical models, process-based models have the ability to make predictions outside the range of data used in their parameterisation, making them the models of choice for designing plant species mixtures. In order to simulate both competition and facilitation, it is necessary to achieve a balance in aboveground and belowground interactions in resource capture by the component species. Moreover, in modelling approaches, a balance needs to be maintained between process and pattern, between temporal and spatial aspects. Multispecies dynamic models for resource partition must include appropriate plasticity mechanisms in the plant models, solve the resource sharing for multiple resources simultaneously, and couple plant and crop models often built with different concepts (Fig. 6).

\subsubsection{A review of current multispecies system models}

A comparison of some representative multispecies system models is presented (Tab. II). Relatively few models have been developed for mixtures of tree species (Bartelink, 
Table II. Comparison of some multispecies models designed for intercropping, agroforestry and forestry.

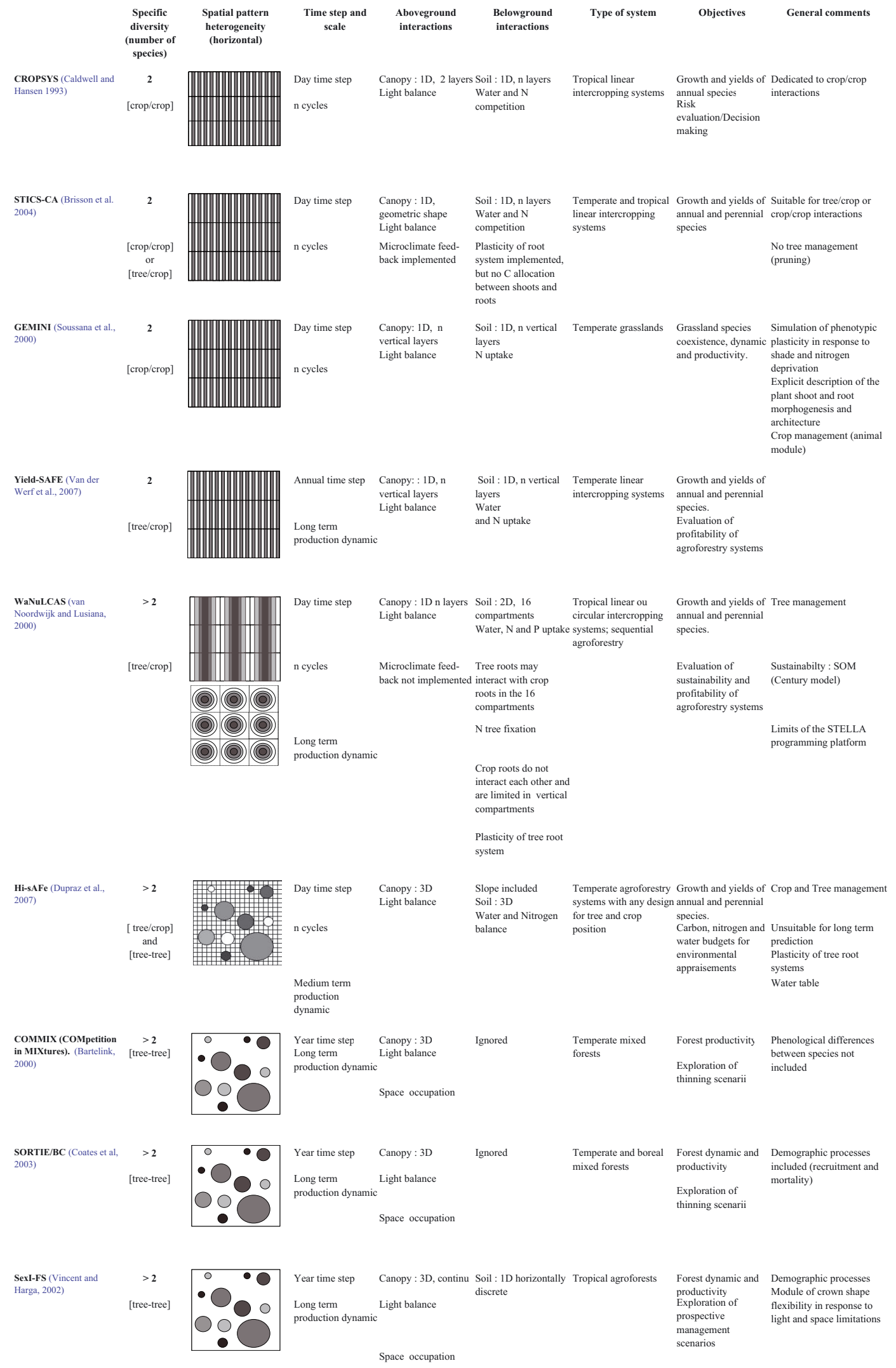


2000; Coates et al., 2003) and mixtures of herbaceous species (Brisson et al., 2004; Caldwell and Hansen, 1993; Carberry et al., 1996; Tsubo et al.,2005), including crop-weed models (Deen et al., 2003), but even fewer for mixtures of trees and crops (Garcia-Barrios and Ong, 2004; Mobbs et al., 1998). Competition models for trees only usually run on a yearly time step, while competition models for crops only, or crops and trees, run on a daily time step.

Multispecies system models can be divided into three groups depending on spatial discretisation of the simulated scene. Most models ignore the spatial heterogeneity of plant mixtures, and simplify the system to a one-dimensional representation. They include CROPSYS (Caldwell and Hansen, 1993), APSIM (Carberry et al., 1996), Yield-sAFe (van der Werf et al., 2007), and GEMINI (Soussana and Lafarge, 1998). Those models mimic sole crop modelling, considering the system to be composed of two species instead of one, and assume that both aboveground and belowground stand components are horizontally homogeneous. In the second group of models, a first level of spatial heterogeneity is introduced through discretisation of the system into some linear or circular areas between which flows of mass or energy occur. Some intercropping models such as STICS-CA (Brisson et al., 2004) and most tree belt-crop models (Huth et al., 2003) follow that approach. The WaNuLCas model (Van Noordwijk and Lusiana, 1998) includes 4 zones of tree-crop interactions with decreasing intensity. The possible schedule of a sequence of crops to be grown over time in each zone makes it possible to encompass a broader range of systems in terms of species diversity and spatial structure. The third group includes spatially explicit models, based on modelling individual plants that interact together. This is most common for trees in mixed stands (Bartelink, 2000; Coates et al., 2003) but those models often ignore belowground interactions and focus on light partitioning between trees. Very few spatially-explicit models have been developed for annual plants; some models deal with grassland mixtures (Soussana and Loiseau, 2002), but most are neighbourhood population dynamic models that often ignore competition for belowground resources (Stephen et al., 1990). SeXI-FS (Manson et al., 2006; Vincent and Harja, 2002) and Hi-sAFe (Dupraz et al., in prep) are models that explicitly integrate both above- and belowground competition for resources on a plant scale, using a distance-dependent and an individual-based modelling approach. By including demographic processes (mortality, recruitment), SeXI-FS simulates the long-term dynamics of the spatial structure. For belowground interactions, progress has been achieved with the development of $2 \mathrm{D}$ mechanistic models that include distributed source-sink functions (Ozier-Lafontaine et al., 1998; Lafolie et al., 1999), and in some cases algorithms to account for minimum energy resolution (Adiku et al., 2000). By coupling structure and function at different levels of complexity, these biophysical models provide a clearer understanding of the importance of the different components involved in water competition, i.e. demand partitioning, soil hydrodynamic properties, root distribution and priority in root water extraction.

Time steps in all these models vary from 1 year to one day or less, with possible integration over the course of one or more growing seasons, up to a century for forest models. The models have not been designed for the same purpose, or for the same users, and a comparison is therefore tricky. They often combine simplicity and complexity: one model might be very simple regarding one mechanism, while being more realistic and close to mechanistic models for simulating other processes. Most of the models are used as research tools rather than management tools. Knowledge gaps have been identified and are discussed in the following section.

\subsection{Future directions in modelling plant mixtures}

\subsubsection{Designing an appropriate working environment to deal with spatial and temporal patterns}

One of the main characteristics of multispecies systems is the wide range of spatial arrangements (strip or mixed systems, alley crops with various plant-plant distances, mixtures of annuals and perennials, vertical discontinuities in agroforests, windbreaks, etc.) and temporal arrangements (simultaneous versus sequential) that farmers opt for depending on their agroecological purposes. Such a platform is only partially designed in WaNulCAS and Hi-sAFe for agroforestry systems. A real breakthrough is needed in the design of a flexible platform that involves both multi-spatial and temporal management, including annual (intercrops, cover crops) and perennial (agroforests, forests) arrangements. The CAPSIS platform provides an attractive example of such operational platforms designed for the simulation of forest dynamics and productivity.

Dynamic simulation models need to integrate competition for different resources in time and space, so as to predict highly non-linear response patterns. A key point in future modelling challenges remains the need for a link between different models geared towards process levels and, above all, between different spatial and temporal scales. That objective means creating bridges between ecophysiology, population biology and functional ecology.

Table II focuses on the modelling of multispecies systems as a whole, but other modelling tools are available and relevant to the analysis of some multispecies system processes or components. For example, radiation models based on 3D architectural mock-ups and ray-tracing can be used to derive parameters of the turbid medium analogy widely applied in multispecies system models (Lamanda et al., 2007). In addition, conceptual population biology models may be helpful in exploring the coexistence of species in mixtures. To that end, use of functional traits and groups used in ecology to characterise and simulate natural ecosystems such as rainforests (Gourlet-Fleury et al., 2005) may be of great interest for simulating complex multispecies systems, such as agroforestry systems in the humid tropics (Malézieux et al., 2007). 


\subsubsection{Challenges related to the level of process description in mechanistic models}

The large number of possible species combinations, management practices and site-dependent interactions in multispecies systems indicates that a pure empirical approach would be unsuitable for most problems to be solved. Although intensive work has been devoted to simulating abiotic interactions (light, water) in multispecies systems, efforts need to be focused on (i) better knowledge of interactions for resources, which requires both suitable discretisation of the above- and belowground environment (voxellisation) and realistic simulation of the physical properties of mass transport laws - simulation of changes in soil physical properties, due to tillage and biological activities, must also receive greater attention (Stockle, 1999) - and (ii) an appropriate understanding and multi-scale representation of the plasticity of roots, shoots and crowns involved in the process of adaptation to heterogeneous and competitive environments. Through its decisive role in resource acquisition and use, physiological and morphological plasticity may alter the sign and magnitude of interactions among plants and, as a consequence, the performance and dynamics of the system (Callaway et al., 2003).

Biotic investigations still remain the poor relation of modelling research on multispecies systems, although many models have been developed to simulate the growth and activity of weed, pest and disease populations (Doyle, 1997; Van Oijen, 1995). As pointed out by Stockle (1999), weed, pest and disease effects are ignored in most comprehensive models, as a result of the complexity of dealing with a potentially large number of species for each plant of interest. This field of research is particularly dependent on population ecology concepts - population dynamics, epidemiology - and the functional ecology of the soil (role of micro- and macroorganisms).

In other respects, assessing the impact of climate change and $\mathrm{CO}_{2}$ elevation scenarios on multispecies system productivity and the environment will continue to be an important field of research, particularly for simulating the ability of species to adapt to changing temperatures, moisture availability, atmospheric $\mathrm{CO}_{2}$ concentration and other aspects of climate change, i.e. pest pressure.

\section{CONCLUSION}

Despite its potential advantages and the huge diversity of multispecies systems existing in world agriculture, mainstream agronomic research has largely focused on monocrop systems, with very little interest in ecological interactions between species in mixed systems. Today, it is barely feasible to simulate multispecies systems and, due to the absence of efficient models, it is difficult to understand the effects of the different factors that interact within those systems. The relevance, but relative limitation of the concepts and existing tools of systemic agronomy in alone representing and simulating multispecies systems and their properties certainly reveal the need to find new representations to account for the particular processes brought into play. As shown in this article, the numerous mechanisms involved in species mixing highlight the need to deal with their complexity by combining concepts from diverse disciplines (agronomy, ecology, epidemiology, etc.), although the necessary link with ecology largely remains to be constructed.

As emphasised by Gurr et al. (2003), mixing species in cropping systems may lead to a range of benefits that are expressed on various space and time scales, from a short-term increase in crop yield and quality, to longer-term agroecosystem sustainability, up to societal and ecological benefits that include recreation, aesthetics, water and soil quality, and flora and fauna conservation, including endangered species. Understanding such interactions between cropping systems and the environment means working on a broader spatial scale than the farmer's field and means considering the mosaic of fields that structure the landscape, and its evolution over a longer time scale.

For all these issues, multispecies systems are today a real challenge for agricultural research, and more specifically for systemic agronomy. It is time to understand and integrate their complex functioning and develop an adequate tool-box for checking and ensuring their technological development.

Acknowledgements: We thank the two anonymous referees and the Editor-in-Chief for their helpful comments, and Peter Biggins for English revision. We would like to dedicate this work to our friend and colleague Dr Yves Crozat, a co-author, who sadly passed away before the publication of this article.

\section{REFERENCES}

Abrams P.A. (1995) Monotonic or unimodal diversity - productivity gradient: what does competition theory predict? Ecology 76, 20192027.

Adetiloye P.O., Adekunle A.A. (1989) Concept of monetary equivalent ratio and its usefulness in the evaluation of intercropping advantages, Trop. Agr. 66, 337-340.

Adiku S.G.K., Rose C.W., Braddock R.D., Ozier-Lafontaine H. (2000) On the simulation of the root water extraction: Examination of a minimum energy hypothesis, Soil Sci. 165, 226-236.

Aerts R. (1999) Interspecific competition in natural plant communities: mechanisms, trade-offs and plant-soil feedbacks, J. Exp. Bot. 50, $29-37$.

Altieri M.A. (1999) The ecological role of biodiversity in agroecosystems, Agr. Ecosyst. Environ. 74, 19-31.

Altieri M.A. (2002) Agroecology: the science of natural resource management for poor farmers in marginal environments, Agr. Ecosyst. Environ. 93, 1-24.

Andow D.A. (1991) Yield loss to arthropods in vegetationally diverse ecosystems, Environ. Entomol. 20, 1228-1235.

Andow D.A., Nicholson A.G., Wien H.C., Wilson H.R. (1986) Insect populations on cabbage grown with living mulches, Environ. Entomol. 15, 293-299.

Anil L., Park J., Phipps R.H., Miller F.A. (1998) Temperate intercropping of cereals for forage: a review of the potential for growth and utilization with particular reference to the UK, Grass Forage Sci. 53, 301-317.

Aubry C., Papy F., Capillon A. (1998) Modelling decision-making process for annual crop management, Agr. Syst. 56, 45-65. 
Bartelink H.H. (2000) A growth model for mixed forest stands, Forest Ecol. Manag. 134, 29-43.

Berry D. (2001) Rational chemical control and cultural techniques, in: Marriaud D. (Ed.) Diseases of tropical tree crops, Montpellier, Cirad, pp. 152-192.

Bertness B., Callaway R. (1994) Positive interactions in communities, Trends Ecol. Evol. 9, 191-193.

Bolliger A., Magid J., Amado J.C.T., Skora Neto F., Ribeir M., Calegari A., Ralisch R., de Neergaard A., Donald L.S. (2006) Taking Stock of the Brazilian "Zero Till Revolution": A Review of Landmark Research and Farmers' Practice, Adv. Agr. 91, 47-110.

Brisson N., Bussiere F., Ozier-Lafontaine H., Tournebize R., Sinoquet H. (2004) Adaptation of the crop model STICS to intercropping, Theoretical basis and parameterisation, Agronomie 24, 409-421.

Bruno J.F., Stachowicz J.J., Bertness M.D. (2003) Inclusion of facilitation into ecological theory, Trends Ecol. Evol. 18-3, 119-125.

Brussaard L., de Ruiter P.C., Brown G.G. (2007) Soil biodiversity for agricultural sustainability, Agr. Ecosyst. Environ. 121, 233-244.

Bulson H.A.J., Snaydon R.W., Stopes C.E. (1997) Effects of plant density on intercropped wheat and field beans in an organic farming system, J. Agr. Sci. 128, 59-71.

Caldwell R.M. (1995) Simulation models for intercropping systems, in: Sinoquet H., Cruz P. (Eds.), Ecophysiology of Tropical Intercropping, INRA, Versailles, pp. 353-368.

Caldwell M.M., Richards J.H. (1986) Competing root systems: morphology and models of absorption, in Givnish T. (Ed.), On the economy of plant form and function, Cambridge University Press, pp. 251273.

Caldwell R.M., Hansen J.W. (1993) Simulation of multiple cropping systems with CropSys, in: Penning de Vries F.W.T. (Ed.), Systems Approaches for Agricultural Development, pp. 397-412.

Callaway R.M., Walker L.R. (1997) Competition and facilitation: a synthetic approach to interactions in plant communities, Ecology 78, 1958-1965.

Callaway R.M., Pennings S.C., Richards C.L. (2003) Phenotypic plasticity and interactions among plants, Ecology 84, 1115-1128.

Carberry P.S., Adiku S.G.K., McCown R.L., Keating B.A. (1996) Application of the APSIM cropping systems model to intercropping systems, in: Ito O., Johansen C., Adu-Gyamfi K., Katayama K., Kumar-Rao J.V.D.K., Rego T.J. (Eds.), Dynamics of roots and nitrogen in cropping systems of the semi-arid tropics, Jap. Int. Res. Centre Agric. Sci., pp. 637-648.

Coates K.D., Canham C.D., Beaudet M., Sachs D.L., Messier C. (2003) Use of a spatially explicit individual-tree model (SORTIE/BC) to explore the implications of patchiness in structurally complex forests, Forest Ecol. Manag. 186, 297-310.

Casper B.B., Jackson R.B. (1997) Plant competition underground, Annu. Rev. Ecol. Syst. 28, 545-570.

Clements F.E., Weaver J.E., Hanson H.C. (1926) Plant competition: an analysis of the development of vegetation, Carnegie Institute, Washington.

Coates K.D., Canham C.D., Beaudet M., Sachs D.L., Messier C. (2003) Use of a spatially explicit individual-tree model (SORTIE/BC) to explore the implications of patchiness in structurally complex forests, Forest Ecol. Manag. 186, 297-310.

Coligny F.D., Ancelin P., Cornu G., Courbaud B., Dreyfus P., Goreaud F., Gourlet-Fleury S., Meredieu C., Saint-Andre L. (2003) CAPSIS: computer-aided projection for strategies in silviculture: advantages of a shared forest-modelling platform, in: Modelling forest systems. Workshop on the interface between reality, modelling and the parameter estimation processes, Sesimbra, Portugal, 2-5 June 2002, pp. 319-323.

Corre-Hellou G. (2005) Acquisition de l'azote dans des associations poisorge (Pisum sativum L. - Hordeum vulgare L.) en relation avec le fonctionnement du peuplement. Thèse de doctorat en Sciences Agronomiques de l'École Doctorale d'Angers.
Corre-Hellou G., Fustec J., Crozat Y. (2006) Interspecific competition for soil $\mathrm{N}$ and its interactions with $\mathrm{N}_{2}$ fixation, leaf expansion and crop growth in pea-barley intercrops, Plant Soil 282, 195-208.

Cruz P.A., Sinoquet H. (1994) Competition for light and nitrogen during a regrowth cycle in a tropical forage mixture, Field Crops. Res. 36, 21-30.

Dauzat J., Eroy M.N. (1997) Simulating light regime and intercrop yields in coconut based farming systems, Eur. J. Agron. 7, 63-74.

Deadman M.L., Soleimani M.J., Nkemka P.N. (1996) Cereal clover bicropping: effects on wheat stem-base and root diseases, Brighton crop protection conference.

Deen W., Cousens R., Warringa J., Bastiaans L., Carberry P., Rebel K., Riha S., Murphy C., Benjamin L.R., Cloughley C. (2003) An evaluation of four crop:weed competition models using a common data set, Weed Res. 43, 116-129.

Dempster J.P., Coaker T.H. (1974) Diversification of crop ecosystems as a means of controlling pests, in: Jones D.P., Soloman M.E. (Eds.), Biology in pest and disease control. Wiley and Sons, New York, pp. $106-114$.

Donald C.M. (1958) The interaction of competition for light and for nutrients, Aust. J. Agr. Res. 9, 421-435.

Donald P. (2004) Biodiversity Impacts of Some Agricultural Commodity Production Systems, Conserv. Biol. 18, 17-38.

Doré T., Le Bail M., Martin P., Ney B., Roger-Estrade J. (2006) L'agronomie aujourd'hui, Éditions Quae, ISBN 2-7592-0000-0, 367 p.

Doré T., Clermont-Dauphin C., Crozat Y, Jeuffroy M.H., Loyce C., Makowski D., Malézieux E., Meynard J.M., Valantin-Morison M. (2008) Methodological progress in on-farm regional agronomic diagnosis, Agron. Sustain. Dev. 28 dx.doi.org/10.1051/agro:2007031.

Doyle C.J. (1997) A review of the use of models of weed control in Integrated Crop Protection, Agr. Ecosyst. Environ. 64, 165-172.

Dupraz C. (1998) Adequate design of control treatments in long term agroforestry experiments with multiple objectives, Agroforest. Syst. 43, 35-48.

Dupraz C., Vincent G., Lecomte I., Noordwijk M.V. (in prep) Modelling 3D interactions of trees and crops with the Hi-sAFe model.

Dury S., Temple L. (1999) La diversification fruitière des exploitations périurbaines dans la région de Yaoundé (Cameroun). Quelles conséquences pour l'orientation de la recherche-développement ? in: Actes du Symposium international "Jardin Planétaire 99", Savoie Technolac, Prospective 2100, Chambéry, France, pp. 531-535.

Egunjobi O.A. (1984) Effects of intercropping maize with grain legumes and fertilizer treatments on populations of Protylenchus penetrans Godfrey (Nematoda) and on the yield of maize (Zea mays L.), Prot. Ecol. 6, 153-167.

Eichhorn M., Paris P., Herzog F., Incoll L., Liagre F., Mantzanas K., Mayus M., Moreno G., Papanastasis V., Pilbeam D. (2006) Silvoarable Systems in Europe: Past, Present and Future Prospects, Agroforest. Syst. 67, 29-50.

Erskine P.D., Lamb D., Bristow M., (2006) Tree species diversity and ecosystem fonction: can tropical multi-species plantations generate greater productivity? Forest Ecol. Manag. 233, 205-210.

Ewel J.J. (1986) Designing agricultural ecosystems for the humid tropics, Ann. Rev. Ecol. Syst. 17, 245-271.

Ewel J.J. (1999) Natural systems as models for the design of sustainable systems of land use, Agroforest. Syst. 45, 1-21.

Ewel J.J., Bigelow S.W. (1996) Plant life-forms and tropical ecosystem functioning, Ecol. Stud. 122, 101-126.

Follis M.B. (1993) Economic considerations, in: Nair P.K.R. (Ed.), Introduction to Agroforestry, Kluwer Academic Publishers, Dordrecht, pp. 385-411.

Francis C.A. (1990) Potential of multiple cropping systems, in: Altieri M.A., Hecht S.B. (Eds.), Agroecology and small farm development, Boca Raton, Florida, CRC Press, pp. 137-150. 
Frank D.A., McNaughton S.J. (1991) Stability increases with diversity in plant communities: empirical evidence from the 1998 Yellowstone drought, Oikos 62, 360-362.

Garcia-Barrios L. (2003) Plant-plant interactions in tropical agriculture, in: Vandermeer J. (Ed.), Tropical Agroecosystems, CRC Press, pp. 11-58.

Garcia-Barrios L., Ong C.K. (2004) Ecological interactions, management lessons and design tools in tropical agroforestry systems, Agroforest. Syst. 61/62, 221-236.

Giller K.E., Beare M.H., Lavelle P., Izac M.N., Swift M.J. (1997) Agricultural intensification, soil biodiversity and agroecosystem function, Appl. Soil Ecol. 6, 3-16.

Gliesmann S.R. (2001) Agroecosystem sustainability: developing practical strategies, CRC Press, Boca Raton, Florida, USA.

Goldberg D.E., Barton A.M. (1992) Patterns and consequences of interspecific competition in natural communities: a review of field experiments with plants, Am. Nat. 139, 771-801.

Gooding M.J., Kasyanova E., Ruske R., Hauggaard-Nielsen H., Jensen E.S., Dahlmann C., Von Fragsten P., Dibet A., Corre-Hellou G., Crozat Y., Pristeri A., Romeo M., Monti M., Launay M. (2007) Intercropping with pulses to concentrate nitrogen and sulphur in wheat, J. Agr. Sci. 145, 469-479.

Gosse G., Varlet-Grancher C., Bonhomme R., Allirand J.M., Lemaire G. (1986) Production maximale de matière sèche et rayonnement solaire intercepté par un couvert végétal, Agronomie 6, 47-56.

Gourlet-Fleury S., Blanc L., Picard N., Sist P., Dick J., Nasi R., Swaine M.D., Forni E. (2005) Grouping species for predicting mixed tropical forest dynamics: looking for a strategy, Ann. For. Sci. 62, 785796.

Gregory P.J., Reddy M.S. (1982) Root growth in an intercrop of pear millet/groundnut, Field Crop. Res. 5, 241-252.

Griffon M. (1999) Développement durable et agriculture : la révolution doublement verte, Cah. Agric. 8, 259-267.

Grime J.P. (1977) Evidence for the existence of three primary strategies in plants and its relevance to ecological and evolutionary strategy, Am. Nat. 111, 1169-1194.

Gurr G.M., Wratten S.D., Luna J.M. (2003) Multi-function agricultural biodiversity: pest management and other benefits, Basic Appl. Ecol. $4,107-116$.

Hauggaard-Nielsen H., Jensen E. (2005) Facilitative root interactions in intercrops, Plant Soil 274, 237-250.

Hauggaard-Nielsen H., Ambus P., Jensen E.S. (2001) Interspecific competition, $\mathrm{N}$ use ans interference with weeds in pea-barley intercropping, Field Crop. Res. 70, 101-109.

Hector A., Schmid B., Beierkuhnlein C. (1999) Plant diversity and productivity experiments in European grasslands, Science 286, 1123 1127.

Hiebsch C.K., McCollum R.E. (1987) Area X Time Equivalency Ratio: a method for evaluating the productivity of intercrops, Agron. J. 79, $15-22$.

Hobbs R.J., Morton S.R. (1999) Moving from descriptive to predictive ecology, Agroforest. Syst. 45, 43-55.

House J.I., Archer S., Breshears D.D., Scholes R.J. (2003) Conundrums in mixed woody-herbaceous plant systems, J. Biogeogr. 30, 17631777.

Huxley P.A. (1983) Comments on agroforestry classifications with special reference to plant aspects, in: Huwley P.A. (Ed.), Plant research and agroforestry, ICRAF, Nairobi, pp. 161-172.

Huth N.I., Carberry P.S., Poulton P.L., Brennan L.E., Keating B.A. (2003) A framework for simulating agroforestry options for the low rainfall areas of Australia using APSIM, Eur. J. Agron. 18, 171-185.

Jackson W. (2002) Natural systems agriculture: a truly radical alternative, Agr. Ecosyst. Environ. 88, 111-117.
Jing Quan Yu (1999) Allelopathic suppression of Pseudomonas solanacearum infection of tomato (Lycopersicon esculentum) in a tomato-chinese chive (Allium tuberosum) intercropping system, J. Chem. Ecol. 25, 11.

Jones G.A., Sieving K.E. (2006) Intercropping sunflower in organic vegetables to augment bird predators of arthropods, Agr. Ecosyst. Environ. 6, 171-177.

Keating B.A., Carberry P.S. (1993) Resource capture and use in intercropping - Solar radiation, Field Crop. Res. 34, 273-301.

Keddy (1989) Competition, Chapman and Hall, New York.

Kelty M.J. (2006) The role of species mixtures in plantation forestry, Forest Ecol. Manag. 233, 195-204.

Kinane J.S., Lyngkjær M. (2002) Effect of barley-legume intercrop on disease in an organic farming system, Annual report of the Danish research centre for organic farming.

Kumar Anil, Solanki K.R., Singh R. (2000) Effect of Wheat as intercrop on incidence of powdery mildew of ber (Zizyphus mauritiana), FACTRR 4, 121-124.

Lafolie F., Bruckler L., Ozier-Lafontaine H., Tournebize R., Mollier A. (1999) Modelling soil-root water transport and competition for single and mixed crops, Plant Soil 210, 127-143.

Lamanda N., Dauzat J., Jourdan C., Martin P., Malézieux E. (2007) Using 3D architectural models to assess light availability and root bulkiness in coconut agroforestry systems, Agroforest. Syst., DOI 10.1007/s10457-007-9068-3.

Lichtfouse E. (1997) Heterogeneous turnover of molecular organic substances from crop soils as revealed by $13 \mathrm{C}$ labeling at natural abundance with Zea Mays, Naturwissenschaften 84, 22-23.

Liebman M., Altieri M.A. (1986) Insect, weed and plant disease management in multiple cropping systems, Editor, MacMillan Publ. Co., N.Y., $383 \mathrm{p}$.

Liebman M., Dick E. (1993) Crop rotation and intercropping strategies for weed management, Ecol. Appl. 3, 92-122.

Lefroy E.C., Hobbs R.J., Connor M.H.O., Pate J.S. (1999) What can agriculture learn from natural ecosystems? Agroforest. Syst. 45, 425438.

Lin C.H., McGraw M.L., George M.F., Garrett H.E. (2001) Nutritive quality and morphological development under partial shade of some forage species with agroforestry potential, Agroforest. Syst. 53, 269-281.

Liu J., Ashton P.S. (1995) Individual-based simulation models for forest succession and management, Forest Ecol. Manag. 73, 157-175.

Loreau M., Hector A. (2001) Partitioning selection and complementarity on biodiversity experiments, Nature 412, 72-76.

Loreau M., Naem S., Inchausti P., Bengtsson J, Grime J.P., Hooper D.U., Huston M.A., Taffaelli D., Schmid B., Tilman D., Wardle D.A. (2001) Biodiversity and ecosystem functioning: current knowledge and future challenges, Science 294, 804-808.

Lose S.J., Hilger T.H., Leihner D.E., Kroschel J. (2003) Cassava, maize and tree root development as affected by various agroforestry and cropping systems in Benin, West Africa, Agr. Ecosyst. Environ. $100,137-151$

Loyce C., Rellier J.P., Meynard J.M. (2002) Management planning for winter wheat with multiple objectives: the BETHA system, Agr. Syst. 72, 9-31.

Main A.R. (1999) How much biodiversity is enough? Agroforest. Syst. $45,23-41$.

Malézieux E., Moustier P. (2005a) La diversification dans les agricultures du Sud : à la croisée de logiques d'environnement et de marché. I. Un contexte nouveau, Cah. Agr. 14, 277-281.

Malézieux E., Moustier P. (2005b) La diversification dans les agricultures du Sud : à la croisée de logiques d'environnement et de marché. II. Niveaux d'organisation, méthodes d'analyse et outils de recherche, Cah. Agr. 14, 375-382. 
Malézieux E., Lamanda N., Laurans M., Deheuvels O., Tassin J., GourletFleury S. (2007) Plant Functional Types and Traits: their relevance to better understand functioning and properties of Agroforestry Systems, 2nd Symposium on multistrata agroforestry, CATIE, Costa Rica (in press).

Manson D.G., Hanan J., Hunt M., Bristow M., Erskine P.D., Lamb D., Schmidt S. (2006) Modelling predicts positive and negative interactions between three Australian tropical tree species in monoculture and binary mixture, Forest Ecol. Manag. 233, 315-323.

Mead R., Willey R.W. (1980) The concept of "land equivalent ratio" and advantages in yields from intercropping, Exp. Agr. 16, 217-228.

Mobbs D.C., Cannell M.G.R., Crout N.M.J., Lawson G.J., Friend A.D., Arah J. (1998) Complementarity of light and water use in tropical agroforests I. Theoretical model outline, performance and sensitivity, Forest Ecol. Manag. 102, 259-274.

Monteith J.L. (1977) Climate and the efficiency of crop production in Britain, Philos. T. Roy. Soc. London, pp. 277-294.

Muschler R.G. (2001) Shade improves coffee quality in a sub-optimal coffee-zone of Costa Rica, Agroforest. Syst. 85, 131-139.

Nair P.K.R. (1993) An introduction to agroforestry, Kluwer Academic publishers, UK, $499 \mathrm{p}$.

Nickel J.L. (1973) Pest situations in changing agricultural systems - a review, Bull. Entomol. Soc. Am. 19, 136-142.

Ogenga-Latigo M.W., Ampofo J.K.O., Balidawa C.W. (1992) Influence of maize row spacing on infestation and damage of intercropped beans by the bean aphid (Aphis fabae), Field Crop. Res. 30, 110122.

Ong C.K., Huxley P. (1996) Tree-crop interactions: a physiological approach, CAB International, Wallingford.

Osty P.L., Lardon S., de Sainte-Marie C. (1998) Comment analyser les transformations de l'activité productrice des agriculteurs ? Proposition à partir des systèmes techniques de production, in Brossier J., Dent B. (Eds.), Gestion des exploitations et des ressources rurales, Étud. Rech. Syst. Agraires Dev. 31, 397-413.

Ozier-Lafontaine H., Vercambre G., Tournebize R. (1997) Radiation and transpiration partitioning in a maize-sorghum intercrop: A comparison of two models, Field Crop. Res. 49, 127-145.

Ozier-Lafontaine H., Lafolie F., Bruckler L., Tournebize R., Mollier A. (1998) Modeling competition for water in intercrops: Theory and comparison with field experiments, Plant Soil 204, 183-201.

Park S.E., Benjamin L.R., Watkinson A.R. (2002) Comparing biological productivity in cropping systems: a competition approach, J. Appl. Ecol. 39, 416-426.

Park S.E., Benjamin L.R., Watkinson A.R. (2003) The Theory and Application of Plant Competition Models: an Agronomic Perspective, Ann. Bot. 92, 741-748.

Perfecto I., Rice R.A., Green Berg, Van der Voort M.E. (1996) Shade coffee: a disappearing refuge for biodiversity, Bioscience 46, 598608

Perfecto I., Mas A., Dietsch T., Vandermeer J. (2003) Conservation of biodiversity in coffee agroecosystems: a tri-taxa comparison in southern Mexico, Biodivers. Conserv. 12, 1239-1252.

Perrin R.M. (1977) The role of environmental diversity in crop protection, Prot. Ecology 2, 77-114.

Poggio S.L. (2005) Structure of weed communities occuring in monoculture and intercropping of field pea and barley, Agr. Ecosyst. Environ. 109, 48-58.

Price C. (1995) Economic evaluation of financial and non-financial costs and benefits in agroforestry development and the value of sustainability, Agroforest. Syst. 30, 75-86.

Price G.R. (1970) Selection and covariance, Nature 227, 520-521.

Price G.R. (1995) The nature of selection, J. Theor. Biol. 175, 389-396.

Prusinkiewicz P. (2004) Modelling plant growth and development, Curr. Opin. Plant Biol. 7, 79-83.
Ramirez O.A., Somarriba E., Ludewigs T., Ferreira P. (2001) Financial returns, stability and risk of cacao-plantain-timber agroforestry systems in Central America, Agroforest. Syst. 51, 141-154.

Ranganathan R. (1992) Production possibility frontiers and estimation of competition effects: the use of a priori information on biological processes in intercropping, Exp. Agr. 28, 351-367.

Rajvanshi I., Mathur B.N., Sharma G.L. (2002) Effect of intercropping on incidence of Heterodera avenae in wheat and barley crops, Annu. Plant Protection Sci. 10, 365-410.

Rodriguez-Cabana R., Kloepper J.W. (1998) Cropping systems and the enhancement of microbial activities antagonistic to nematodes, Nematropica 28, 144.

Rossing W.A.H., Jansma E.J., de Ruijter F.J., Schans J. (1997) Operationalizing sustainability: exploring options for environmentally friendly flower buble production systems, Eur. J. Plant Pathol. 103, 217-234.

Root R.B. (1973) Organization of a plant-arthropod association in simple and diverse habitats - fauna of collards (Brassica oleracea), Ecol. Monogr. 43, 95-120.

Sain G., Ponce I., Borbon E. (1994) Profitability of the Abonera system practiced by farmers on the Atlantic Coast of Honduras, in: Thurston H.D., Smith M., Abawi G., Kearl S. (Eds.), TAPADO Slash/mulch: how farmers use it and what researchers know about it, CATIE and CIIFAD, Ithaca, New York, pp. 273-282.

Scopel E., Da Silva F.A.M., Corbeels M., Affholder F., Maraux F. (2004) Modelling crop residue mulching effects on water use and production of maize under semi-arid and humid tropical conditions, Agronomie 24, 383-395.

Scopel E., Findeling A., Chavez Guerra E., Corbeels M. (2005) Impact of direct sowing mulch-based cropping systems on soil carbon, soil erosion and maize yield, Agron. Sustain. Dev. 25, 425-432.

Sébillotte M. (1974) Agronomie et agriculture, analyse des tâches de l'agronome, Cah. Orstom, série Biol. 24, 3-25.

Sébillotte M. (1978) Itinéraires techniques et évolution de la pensée agronomique, CR Acad. Agric. France 11, 906-913.

Sébillotte M. (1990) Système de culture, un concept opératoire pour les agronomes, in: Combe L., Picard D. (Eds.), Les systèmes de culture, Paris, INRA, pp. 165-196.

Shelton A.M., Badenes-Perez F.R. (2006) Concepts and applications of trap cropping in pest management, Annu. Rev. Entomol. 51, 285308.

Sherr S., Milder J.C., Inbar M. (2007) Paying farmers for Stewardship, in: Sherr S., Mac Neely J.A. (Eds.), Farming with Nature, Island Press, Washington.

Sibma L., Kort J., De Wit C.T. (1964) Experiments on competition as a means of detecting possible damage by nematodes, Jaarb Inst. Biol. Scheiks 1964, 119-124.

Sinoquet H., Caldwell R.M. (1995) Estimation of light capture and partitioning in intercropping systems, in: Sinoquet H., Cruz P. (Eds.), Ecophysiology of Tropical Intercropping, INRA, Paris, pp. 79-97.

Soussana J.-F., Lafarge L. (1998) Competition for resources between neighbouring species and patch scale vegetation dynamics in temperate grasslands, Ann. Zootech. 47, 371-382.

Soussana J.F., Loiseau P. (2002) A grassland ecosystem model with individual based interactions (GEMINI) simulates fluctuations in the clover content of sown mixtures, in: Multi-function grasslands: quality forages, animal products and landscapes, Proceedings of the 19th General Meeting of the European Grassland Federation, La Rochelle, France, 27-30 May 2002, pp. 358-359.

Stephen W., Pacala J.A., Silander J. (1990) Field Tests of Neighborhood Population Dynamic Models of Two Annual Weed Species, Ecol. Monogr. 60, 113-134.

Stockle C.O. (1999) Simulation of agricultural systems: the challenges ahead, in: Proceedings of the International Symposium Modelling Cropping Systems, pp. 19-24, LLeida, Catalonia, Spain. 
Swift M.J., Anderson J.M. (1993) Biodiversity and ecosystem function in agroecosystems, in: Shultze E., Mooney H.A. (Eds.), Biodiversity and ecosystem function, Springer, New York, pp. 57-83.

Swift M.J., Vandermeer J.H., Ramakrishnan P.S., Anderson J.M., Ong C., Hawkins B. (1996) Biodiversity and agroecosystem function, in: Mooney et al. (Eds.), Biodiversity and ecosystem function, Global diversity assessment, Cambridge University Press, pp. 433-443.

Swift M.J., Izac A.M.N., Van Noordwijk M. (2004) Biodiversity and ecosystem services. Are we asking the right questions? Agr. Ecosyst. Environ. 104, 113-134.

Tilman D. (1984) Plant dominance along an experimental nutrient gradient, Ecology 65, 1445-1453.

Tilman D. (1988) Plant strategies and the dynamics and structures of plant communities, Princeton University Press, Princeton, NJ, USA.

Tilman D., Wedin D., Knops J. (1996) Productivity and sustainability influenced by biodiversity in grasslands ecosystems, Nature 379 , $718-720$.

Tilman D., Knops J., Wedin D., Reich P., Ritchie M., Siemann E. (1997) The influence of functional diversity and composition on ecosystem processes, Science 277, 1300-1302.

Tilman D., Cassman K., Matson P., Naylor R., Polasky S. (2002) Agricultural sustainability and intensive production practices, Nature 418, 671-677.

Tixier P., Malezieux E., Dorel M. (2004) SIMBA-POP: a cohort population model for long-term simulation of banana crop harvest, Ecol. Model. 180, 407-417.

Torquebiau E. (2000) A renewed perspective on agroforestry concepts and classification, C.R. Acad. Sci. Paris 1009-1017.

Trenbath B.R. (1974) Biomass productivity of mixtures, Adv. Agron. 26, 177-209.

Trenbath B.R. (1993) Intercropping for the management of pests and diseases, Field Crop. Res. 34, 381-405.

Tsubo M., Walker S., Ogindo H.O. (2005) A simulation model of cereallegume intercropping systems for semi-arid regions: I. Model development, Field Crop. Res. 93, 10-22.

Van der Werf W., Keesman K., Burgess P., Graves A., Pilbeam D., Incoll L.D., Metselaar K., Mayus M., Stappers R., van Keulen H. et al. (2007) Yield-SAFE: A parameter-sparse, process-based dynamic model for predicting resource capture, growth, and production in agroforestry systems, Ecological Engineering (in press).

Van Noordwijk M., Lawson G., Soumaré A., Groot J.J.R., Hairiah, K., (1996) Root distribution of trees and crops: competition and/or complementarity, in: Ong C.K., Huxley P.W. (Eds.), TreeCrop Interactions: A Physiological Approach, CAB International, Wallingford, UK, pp. 319-364.

Van Noordwijk M., Lusiana B. (1998) WaNuLCAS, a model of water, nutrient and light capture in agroforestry systems, Agroforest. Syst. 43, 217-242.

Van Oijen M. (1995) Simulation models of potato late blight, in: Haverkort A.J., MacKerron (Eds.), Potato Ecology and Modeling of Crops under Conditions Limiting Growth, Kluwer Academic Publishers, Dordrecht, pp. 237-250.

Vandermeer J.H. (1989) The Ecology of Intercropping, Cambridge University Press, Cambridge, UK.

Vandermeer J., Van Noordwijk M., Anderson J., Ong C., Perfecto I. (1998) Global change and multi-species ecosystems: concepts and issues, Agr. Ecosyst. Environ. 67, 1-22.

Vila M., Vayreda J., Gracia C., Ibanez J.J. (2003) Does tree diversity increase wood production in pine forests? Oecologia 135, 299-303.

Vincent G., Harja D. (2002) SLIM software: a simple light interception model for multi-species, multi-strata forests, Bois Forêts des Tropiques 2, 97-100.

Wallace J.S., Batchelor C.H., Dabeesing D.N., Teeluck M., Soopramanien G.C. (1991) A comparison of the light interception and water-use of plant and first ratoon sugar-cane intercropped with maize, Agr. Forest Meteorol. 57, 85-105.

Welsh J.P., Philipps L., Bulson H.A.J., Wolfe M. (1999) Weed control for organic cereal crops. Proceedings of the Brighton Crop Protection Conference - Weeds, Brighton, UK, pp. 945-950.

Willigen De P., Van Noordwijk M. (1987) Roots, plant production and nutrient use efficiency, Ph.D. Thesis, Wageningen Agricultural University, $281 \mathrm{p}$.

Wit de C.T., Van Den Berg J.P. (1965) Competition between herbage plants, Neth. J. Agr. Sci. 13, 212-221.

Wilson S.D., Tilman D. (1988) Components of plant competition along an experimental gradient of nitrogen availability, Ecology 72, 10501065.

Wong S.C., Osmond C.B. (1991) Elevated atmospheric partial pressure of $\mathrm{CO}_{2}$ and plant growth III. Interaction between Triticum aestivum (C3) and Echinocloea fumentacea (C4) during growth in mixed culture under different $\mathrm{CO}_{2}, \mathrm{~N}$ nutrition and irradiance treatments, with emphasis on below ground responses, estimated using a 13C value of root mass, Aust. J. Plant Phys. 18, 137-152.

Yeates G.W. (1987) How plants affect nematodes, Adv. Ecol. Res. 17, 61-113. 